\title{
Agro-ecological benefits of faba bean for rainfed Mediterranean cropping systems
}

\author{
Paolo Ruisi, ${ }^{1}$ Gaetano Amato, ${ }^{1}$ Giuseppe Badagliacca, ${ }^{1}$ Alfonso Salvatore Frenda, ${ }^{1}$ \\ Dario Giambalvo, ${ }^{1,2}$ Giuseppe Di Miceli, ${ }^{1,2}$ \\ ${ }^{1}$ Department of Agricultural, Food and Forest Sciences, University of Palermo, Palermo; ${ }^{2}$ A. \& S. Lima \\ Mancuso Foundation, Palermo, Italy
}

\begin{abstract}
This paper reviews the main results from a set of experiments carried out in a semiarid Mediterranean environment during the past 25 years on faba bean (Vicia faba L.), a crop traditionally grown in southern Italy and Sicily under rainfed conditions. These experiments focused on the residual effects of faba bean on subsequent crop(s) and assessment of the nitrogen (N) balance during the crop cycle, paying attention to both the environmental release of $\mathrm{N}$ (losses via volatilisation and denitrification) and estimates of $\mathrm{N}_{2}$ fixation as influenced by tillage system, intercropping, and presence/absence of mycorrhizal inoculum. Faba bean relied on $\mathrm{N}_{2}$ fixation more than other grain legumes typically grown in the Mediterranean region (e.g., chickpea). Contributing reasons were the higher plant $\mathrm{N}$ demand of faba bean and its lower capacity to use soil mineral $\mathrm{N}$. This implies higher $\mathrm{N}$ benefits for subsequent crop(s) as well as higher risk of $\mathrm{N}$ losses from the plant-soilatmosphere system via leaching, denitrification, and volatilisation. Results from these experiments contribute to better defining the
\end{abstract}

Correspondence: Paolo Ruisi, Department of Agricultural, Food and Forest Sciences, University of Palermo, Viale delle Scienze Ed. 4, 90128, Palermo, Italy.

E-mail: paolo.ruisi@unipa.it

Key words: Vicia faba L.; Crop rotation; Grain legume; N sparing; $\mathrm{N}_{2}$ fixation.

Acknowledgements: Department of Agricultural, Food and Forest Sciences, University of Palermo and A. \& S. Lima Mancuso Foundation were funded by: MiRAAF (project Sperimentazione per il miglioramento del grano duro in Sicilia); Research Consortium CORERAS (project Leguminose da granella: ruolo nutrizionale ed agro-ambientale); MiPA-UE (project POM A16 Misura 2); Sicilia Region (Patti territoriali Magazzolo-Platani and project SICOBIO); MiPAF (project SICOBIOS); MIUR-UE (PON01_01145-ISCOCEM).

Received for publication: 7 November 2016.

Revision received: 7 April 2017.

Accepted for publication: 10 April 2017

(C) Copyright P. Ruisi et al., 2017

Licensee PAGEPress, Italy

Italian Journal of Agronomy 2017; 12:865

doi:10.4081/ija.2017.865

This article is distributed under the terms of the Creative Commons Attribution Noncommercial License (by-nc 4.0) which permits any noncommercial use, distribution, and reproduction in any medium, provided the original author(s) and source are credited. role of faba bean in Mediterranean agro-ecosystems and to identifying technical solutions that maximise the potential benefits of faba bean as a fertility-building crop.

\section{Introduction}

Faba bean (Vicia faba L.) is one of the oldest grain legume crops. Seeds of the species can be traced back about 10,000 years to northwestern Syria, so it has been suggested that it be added to the list of eight species considered crop founders (Tanno and Willcox, 2006). In its long history, this species has been grown over a wide latitude range for many uses, including as food (dry, fresh, canned, frozen), feed, forage, and green manure. Recently the species has been evaluated for its potential to produce either biogas or ethanol (Petersson et al., 2007). The protein fraction could be used for animal feed and the carbohydrate-rich fraction for biofuel production, as proposed for other legumes (Lamb et al., 2014; Amato et al., 2016).

The seeds of faba bean are valuable for human and animal nutrition mainly because of their high protein content (which can be greater than $30 \%$ on a dry matter basis) and energy supply (a starch content usually greater than $40 \%$ ). Faba bean seeds may contain some compounds (as tannins, vicine, and convicine) that may cause health problems in particular situations. However, great genetic variability has been observed, and new varieties with little or none of these compounds are now available. The health benefits of a faba bean-enriched diet are due to the fiber, vitamin, and mineral content (Champ, 2002; Ofuya and Akhidue, 2005) and include a decrease in plasma low-density lipoprotein cholesterol (Frühbeck et al., 1997).

Despite its long history of use as food and feed, from the beginning of the 1960s to the beginning of the 1990s faba bean cultivation worldwide decreased from more than 5 million hectares to about 2 million hectares (Figure 1). This decline was particularly strong in China, where the cultivated area decreased from about 3.6 million hectares in 1961 (66\% of the total area) to about 0.8 million hectares in 1991 (39\%). During the past 20 years the global area devoted to faba bean cultivation has remained stable at an average of 2.4 million hectares. From 1961 to 2013, the grain yield on average increased from 1.0 to $1.7 \mathrm{Mg} \mathrm{ha}^{-1}$ (however, this increase was less than that observed for the major cereals), and therefore the world's production experienced a total reduction of about $15 \%$.

The Mediterranean basin is one of the regions where faba bean was historically cultivated and used for food and feed. At the beginning of the 1960s the species was cultivated on more than 1.1 million hectares, but a marked decrease in this area was observed in the mid-1990s, mainly because of the dramatic decline in cultivation in Italy (from approximately 540,000 to 
40,000 ha; Figure 2). In contrast, in the North African and West Asian countries of the Mediterranean basin crop surface area was on the whole quite stable.

In southern European countries, particularly in Italy, the decline of the species was mainly due to the substitution in animal feed to predominantly imported soybean grains and cakes. For example, while Italian faba bean production declined from about $400,000 \mathrm{Mg}$ (in 1961) to about 70,000 Mg (in 2013), the importing of soybean (seeds and cakes) increased from about $220,000 \mathrm{Mg}$ (in 1961) to about 3.2 million $\mathrm{Mg}$ (in 2013). However, the crop was also abandoned because of its lower profitability compared to other cash crops (particularly cereals) and the strong unreliability of its grain yield. The minor gain in terms of grain yield and stability observed with faba bean compared to other crops, particularly wheat, is in turn due to the lack of agronomical and genetic research. In fact, in the Mediterranean regions, farmers frequently use local populations because of the limited availability of improved varieties suited to the semiarid environment. Furthermore, the crop is often cultivated using traditional methods, as very few innovative techniques have been promoted, particularly for the control of parasites and weeds.

Reintroducing faba bean and other grain legumes into Mediterranean rainfed cropping systems involves several agronomic, environmental, and ecological services and is in line with the need to reduce the negative impact of agriculture on the environment by reducing the use of nonrenewable resources and chemicals. In fact, because of its ability to fix atmospheric nitrogen (N) by means of symbiosis with Rhizobium, faba bean, as well as other legumes, could contribute to reducing energy use for manufacturing, transporting, and supplying synthetic $\mathrm{N}$ fertilisers. Moreover, the reduced use of energy (mainly derived from fossil fuels) as well as the reduced emission of nitrous oxide compared to $\mathrm{N}$-fertilised non-legume crops (Rochette and Janzen, 2005) can substantially reduce the greenhouse gas emissions of the entire cropping system. Furthermore, faba bean contributes to the improvement of the entire cropping system through crop diversification, enhanced yields of subsequent crops, improvements to the soil, and positive effects in terms of pest and weed control.

The aim of this paper is to review the results of a set of experiments carried out on faba bean in the Mediterranean environment during the past 25 years to better understand the potential role of the species in improving the sustainability of rainfed cropping systems of the Mediterranean region and to identify technical solutions that maximise the potential benefits of faba bean as a fertility-building crop.

\section{Study area}

All experiments (whose basic description is reported in Table 1) were conducted under rainfed conditions at the Pietranera farm (Santo Stefano Quisquina, AG, Italy; 37³0' N, 1331' E), which is located in a hilly area of the Sicilian inland. The farm covers approximately 700 ha and has a variety of soil types, morphologies, and orographies. It has a semiarid Mediterranean climate with a mean annual rainfall of $552 \mathrm{~mm}$, most of which falls in the autumn/winter (74\%) and spring (18\%). There is a dry period from May to September. The mean air temperature is $15.9^{\circ} \mathrm{C}$ in autumn, $9.8^{\circ} \mathrm{C}$ in winter, and $16.5^{\circ} \mathrm{C}$ in spring.

During the 25-year period in which the experiments were performed a high variability for total annual rainfall was recorded (range from 276 to $866 \mathrm{~mm}$ ). Moreover, the field experiments analysed in this paper were conducted in various soils (classified as Typic Calcixerept, Vertic Haploxerept, Chromic Haploxerert; USDA Soil Taxonomy, 2010) that differed in their physical, chemical, and mineralogical characteristics [range for clay content: 26.7-57.2\%; range for sand content: $27.0-48.6 \%$; range for total C (Walkley-Black): 0.63-1.68\%; range for $\mathrm{pH}\left(1: 2.5 \mathrm{H}_{2} \mathrm{O}\right)$ : 7.5-8.5].

\section{Yield, yield stability, and benefits for subsequent crops}

Among the reasons for the gradual decline in grain legumes (and particularly faba bean) in the Mediterranean areas are low productivity (which often results in low income for famers) and the high yield instability. A comparison of the grain yields of different crops grown under the same pedo-climatic conditions obtained from our experiments showed an average grain yield in faba bean $40 \%$ that of wheat (1.8 vs $4.5 \mathrm{Mg} \mathrm{ha}^{-1}$, respectively; 25-year average data) and a much higher variability in production than in the other crops under investigation (coefficient of variation, $\mathrm{CV}=47 \%$ for faba bean $v s \mathrm{CV}=32 \%$ for durum wheat). Faba bean is in fact extremely sensitive to both abiotic (drought, high temperatures)

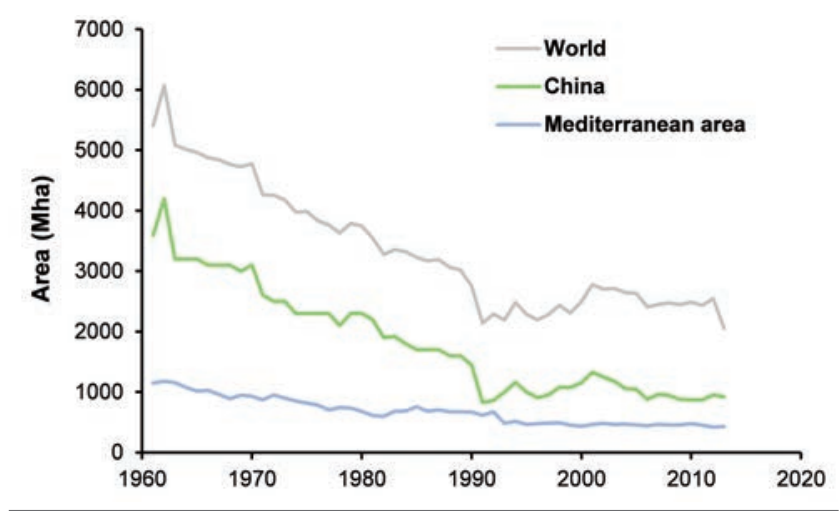

Figure 1. Faba bean cultivation during the period 1961-2013. Elaboration based on data from FAOSTAT (2016).

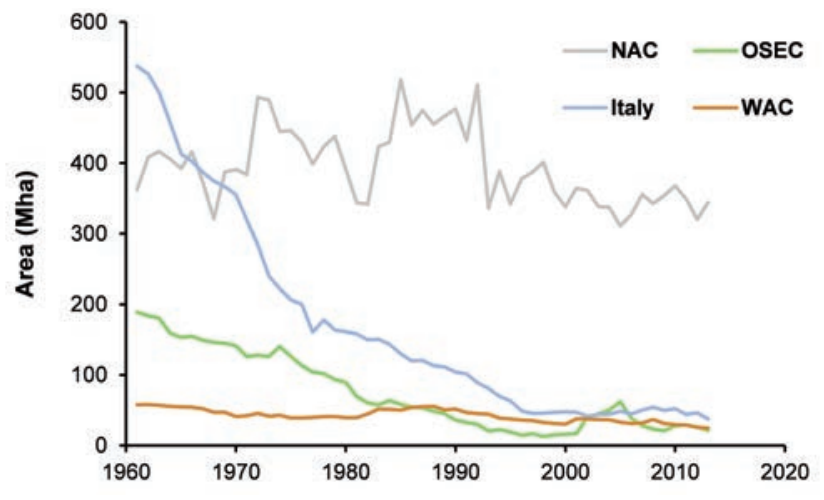

Figure 2. Faba bean cultivation in the Mediterranean basin during the period 1961-2013. NAC, North Africa countries (Algeria, Egypt, Libya, and Tunisia); OSEC, other southern European countries (Albania, Greece, Malta, and Spain); WAC, western Asian countries (Cyprus, Israel, Jordan, Lebanon, Syrian Arab Republic, and Turkey). Elaboration based on data from FAOSTAT (2016). 
and biotic (viruses, fungal diseases, pests, nematodes, weeds) stresses that can markedly affect grain yield. Nevertheless, very little attention has been given to identifying ecological, biological, and edaphic conditions favorable to the growth and health of faba bean (and other grain legumes, such as chickpea, lentil, and grasspea) and thus to defining agronomic strategies able to maximise and stabilise yield. However, a complete assessment of the potential of faba bean needs to take into account the multiple effects that the introduction of this crop has on the entire cropping system.

It is well documented that introducing legumes into the crop rotation has positive effects on subsequent crops, increasing grain yield and enhancing grain quality. In their review, Preissel et al. (2015) reported that in the Mediterranean environment, the grain yield of cereal crops grown after legumes is $0.2-1.5 \mathrm{Mg} \mathrm{ha}^{-1}$ (9$79 \%$ ) greater than the yields obtained after the growth of cereals or sunflower.

In a long-term experiment carried out in a Mediterranean environment (Exp1, see Table 1; and, for further details, see also Ruisi et al., 2015, 2016), in which different tillage techniques and crop sequences were applied, the inclusion of faba bean in the crop sequence resulted in i) a grain yield of the subsequent durum wheat $40 \%$ greater than continuous wheat (Figure 3), which occurred despite a $50 \%$ increase in $\mathrm{N}$ fertilisation in the latter condition (from $80 \mathrm{~kg} \mathrm{~N} \mathrm{ha}^{-1}$ in wheat-faba bean to $120 \mathrm{~kg} \mathrm{~N} \mathrm{ha}^{-1}$ in continuous wheat); ii) an improvement in grain protein content (from $13.6 \%$ in continuous wheat to $14.1 \%$ in wheat-faba bean); and iii) an increase in the grain yield stability of durum wheat with respect to both wheat grown after berseem clover and continuous wheat, as highlighted by lower CV values. The latter result is of considerable importance, especially for the Mediterranean environment, which is characterised, as is well known, by great variability in cli-

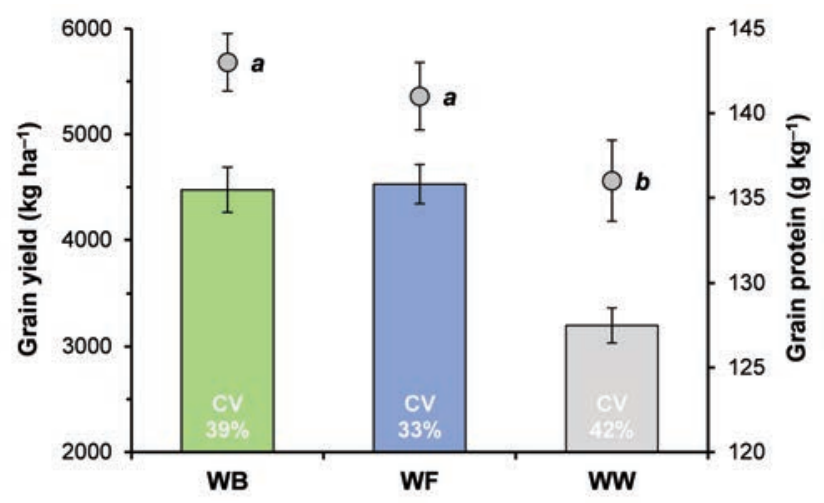

Figure 3. Effects of different crop sequences (WB, wheat-berseem clover; WF, wheat-faba bean; WW, wheat-wheat), applied continuously for 23 years (Exp1; Table 1), on gran yield (histograms) and grain protein (circles) of wheat. Vertical bars represent \pm standard error. CV indicates the coefficient of variation of grain yield. For each trait, different letters denote significant differences among the crop sequences at $P \leq 0.05$.

Table 1. Description of the experiments from which data were sourced.

\begin{tabular}{|c|c|c|c|c|c|}
\hline Experiment & Treatments & $\begin{array}{l}\text { Duration } \\
\text { (years) }\end{array}$ & $\begin{array}{l}\text { Sites } \\
\text { (no.) }\end{array}$ & Methods/Notes & References \\
\hline Expl & $\begin{array}{l}\text { Tillage: CT; NT; RT } \\
\text { Crop sequence: Wheat-berseem clover; } \\
\text { Wheat-faba bean; Wheat-wheat }\end{array}$ & 23 & 1 & $\begin{array}{l}\text { Treatments applied continuously for } 23 \text { years. } \\
\mathrm{N}_{2} \text { fixation estimated in } 2 \text { years using the }{ }^{15} \mathrm{~N} \\
\text { isotope dilution technique (wheat as reference crop) } \\
\text { after } 15 \text { years of continuous application of the treatments. } \\
\text { Ammonia and nitrous oxide emissions estimated after } 22 \text { years } \\
\text { of continuous application of the treatments using respectively } \\
\text { Conway's microdiffusion incubation method and gas } \\
\text { chromatography-electron-capture detection }\end{array}$ & $\begin{array}{l}\text { Giambalvo } \\
\text { et al. (2012); } \\
\text { Amato et al. } \\
\text { (2013) }\end{array}$ \\
\hline
\end{tabular}

\begin{tabular}{|c|c|c|c|c|c|}
\hline Exp2 & $\begin{array}{l}\text { Tillage: CT; NT } \\
\text { Species: Chickpea; Faba bean; Lentil; } \\
\text { Pea; Wheat }\end{array}$ & 4 & $\begin{array}{l}4 \\
\text { (1 site per } \\
\text { year) }\end{array}$ & $\begin{array}{l}\mathrm{N}_{2} \text { fixation estimated using the }{ }^{15} \mathrm{~N} \text { isotope } \\
\text { dilution technique (wheat as reference crop) }\end{array}$ & $\begin{array}{l}\text { Ruisi } \\
\text { et al. }(2001)\end{array}$ \\
\hline Exp3 & $\begin{array}{l}\text { Crop sequence: Wheat-faba bean } \\
\text { (2-year rotation); Wheat-wheat-faba bean } \\
\text { (3-year rotation); Wheat-wheat }\end{array}$ & 6 & 1 & $\begin{array}{l}\text { Crop sequences applied continuously for } 6 \text { years; } \\
\text { experiment carried out under organic farming conditions }\end{array}$ & Unpublished \\
\hline Exp4 & Species: Chickpea; Faba bean; Wheat & 2 & $\begin{array}{l}4 \\
(2 \text { sites per } \\
\text { year) }\end{array}$ & $\begin{array}{l}\mathrm{N}_{2} \text { fixation estimated using the }{ }^{15} \mathrm{~N} \text { isotope dilution technique } \\
\text { (wheat as reference crop) }\end{array}$ & $\begin{array}{l}\text { Giambalvo } \\
\text { et al. }(2003)\end{array}$ \\
\hline Exp5 & $\begin{array}{l}\text { Species: Chickpea; Wheat } \\
\text { N fertilisation: } 0,50,150,300 \mathrm{~kg} \mathrm{~N} \mathrm{ha}^{-1} \\
\text { Inoculation or not with Rhizobium strains }\end{array}$ & 1 & 1 & $\begin{array}{l}\mathrm{N}_{2} \text { fixation estimated using the }{ }^{15} \mathrm{~N} \text { isotope dilution technique } \\
\text { (wheat as reference crop) }\end{array}$ & $\begin{array}{l}\text { Giambalvo } \\
\text { et al. }(2007)\end{array}$ \\
\hline Exp6 & $\begin{array}{l}\text { Species: Chickpea; Faba bean; } \\
\text { Fenugreek; Wheat }\end{array}$ & 2 & $\begin{array}{l}2 \\
\text { (1 site per } \\
\text { year) }\end{array}$ & $\begin{array}{l}\mathrm{N}_{2} \text { fixation estimated using the }{ }^{15} \mathrm{~N} \text { isotope dilution technique } \\
\text { (wheat as reference crop). Measurements made in different } \\
\text { crop phenological stages }\end{array}$ & Unpublished \\
\hline Exp7 & $\begin{array}{l}\text { Species: Chickpea; Faba bean; } \\
\text { Pea; Wheat }\end{array}$ & 2 & 1 & $\begin{array}{l}\mathrm{N} \text { efficiency component analysis in wheat varying } \\
\text { the previous crop }\end{array}$ & $\begin{array}{l}\text { Giambalvo } \\
\text { et al. }(2004)\end{array}$ \\
\hline Exp8 & $\begin{array}{l}\text { Species: Faba bean and Wheat } \\
\text { (grown in sole crop and in intercrop) } \\
\text { Inoculation or not with AM fungi }\end{array}$ & 1 & $\begin{array}{l}\text { Pot } \\
\text { experiment }\end{array}$ & $\begin{array}{l}\mathrm{N}_{2} \text { fixation estimated using the }{ }^{15} \mathrm{~N} \text { natural abundance } \\
\text { technique (wheat as reference crop). } \\
\mathrm{N} \text { transfer estimated through labelling the faba bean } \\
\text { by absorption of the }{ }^{15} \mathrm{~N} \text {-enriched solution via the stem }\end{array}$ & Unpublished \\
\hline
\end{tabular}

CT, conventional tillage; NT, no tillage; RT, reduced tillage. 
mate conditions (mainly erratic rainfall during the growing season) that can markedly affect crop yield and consequently the income of farmers. Under such conditions, in comparison to continuous wheat or even the berseem clover-wheat cropping system, the inclusion of faba bean in the crop sequence could mitigate the possible risks related to variability in climate.

The benefits of faba bean as a previous crop are not exhausted in the year following the cultivation of this legume; on the contrary, these benefits may extend, at a lower level, even to succeeding years. A 6-year study carried out in Sicily by Giambalvo et al. (Exp3, see Table 1) found that the inclusion of faba bean in the cropping system resulted in an increase in the subsequent cereal crop (durum wheat) of about $50 \%$ on average (Figure 4), and moreover significant yield increases were also observed in the second cereal following faba bean $(+11 \%$ on average $)$, confirming the findings of Wright (1990).

In general, the positive effects of faba bean on the performance of the subsequent crop are attributed to both $\mathrm{N}$ and non-N benefits, the former resulting from both the $\mathrm{N}$-sparing effect of the legume and the release of $\mathrm{N}$ mineralised from residues (above and below ground) and the latter resulting from the breaking of pest cycles, a possible reduction of weeds, and a general enhancement of soil fertility. It is difficult to assess the relative importance of these two types of benefits ( $\mathrm{N}$ and non- $\mathrm{N}$ benefits) because, as argued by Jensen et al. (2010), often the two are mixed, with the weight of one or the other varying in relation to various factors, both environmental and agronomic (soil type, climate, crop, agronomic management, etc.). In most literature, the $\mathrm{N}$ benefits play a predominant role, and in this regard a study conducted by us (Giambalvo et al., 2004; Exp7, Table 1) showed that they can exceed $70 \%$ of the total benefit offered by faba bean as preceding crop in comparison with wheat as preceding crop.

\section{Symbiotic nitrogen fixation}

Symbiotic $\mathrm{N}_{2}$ fixation by legumes is a biological process that markedly influences the sustainability of food and feed production. The amount of $\mathrm{N}_{2}$ fixed can vary greatly in relation to many factors, including the soil $\mathrm{N}$ availability, the legume species, its $\mathrm{N}$ demand and ability to accumulate $\mathrm{N}$, environmental conditions that affect crop growth, and so on (Unkovich et al., 2010; Saia et al., 2016). Over the past 25 years, we have made an effort to quantify $\mathrm{N}_{2}$ fixation by faba bean and to clarify to what extent different growing conditions may influence this process. The $\mathrm{N}_{2}$ fixation of faba bean was assessed in several experiments carried out in the field or in pots under a range of soil and climate conditions and types of agronomic management. In all cases, $\mathrm{N}_{2}$ fixation was estimated using ${ }^{15} \mathrm{~N}$ techniques $\left({ }^{15} \mathrm{~N}\right.$ dilution and ${ }^{15} \mathrm{~N}$ natural abundance techniques). The amount of $\mathrm{N}$ fixed by faba bean was on average $128 \mathrm{~kg} \mathrm{~N} \mathrm{ha}^{-1}$, whereas the percentage of faba bean $\mathrm{N}$ derived from symbiotic $\mathrm{N}_{2}$ fixation ( $\% \mathrm{Ndfa}$ ) was on average $74 \%$ (Figure 5; data from Exp1, 2, 4, and 6, see Table 1). These values are in the range of those reported for faba bean in Europe in the review by Jensen et al. (2010). In our experiments, great variation was observed in \%Ndfa (range: $50-93 \%$ ) and especially in the amount of $\mathrm{N}$ fixed (range: $75-229 \mathrm{~kg} \mathrm{~N} \mathrm{ha}^{-1}$ ).

According to Peoples et al. (2009) and Jensen et al. (2010), $\mathrm{N}_{2}$ fixation seemed to be regulated to a greater extent by faba bean growth than by $\% \mathrm{Ndfa}$. In fact, analysing our data from Exp1, 2, 4 , and 6 (Table 1), we found no relation between biomass and $\%$ Ndfa (Figure 6A), whereas a close relationship was observed between biomass and the amount of $\mathrm{N}$ fixed (Figure 6B). Our data suggest that, over the total range of measured values for shoot biomass (from 2 to $13 \mathrm{Mg} \mathrm{ha}^{-1}$ ), around $23 \mathrm{~kg}$ shoot $\mathrm{N}$ was fixed for every megagram of shoot dry matter produced; this value is very close to that reported by Rochester et al. (1998) and by Sulas et al. (2013). An even closer relationship was observed between grain yield and $\mathrm{N}$ fixed (Figure 6C): $56 \mathrm{~kg}$ shoot $\mathrm{N}$ was fixed for every megagram of grain produced. Furthermore, the highly significant linear relationship between $\mathrm{N}$ fixed and total $\mathrm{N}$ uptake found in our experiments (Figure 6D) highlights the possibility of estimating with good precision the amount of $\mathrm{N}$ fixed by faba bean on the basis of such a parameter, similar to the findings of Anglade et al. (2015) and Saia et al. (2016) for forage legumes.

It is well documented that the percentage of Ndfa of a legume is strictly linked to plant-available soil $\mathrm{N}$, as high levels of soil $\mathrm{N}$ availability generally delay the formation of nodules and the onset of $\mathrm{N}_{2}$ fixation (Peoples et al., 1995; van Kessel and Hartley, 2000; Salvagiotti et al., 2008). However, our data (from Exp1, 2, 4, 5, and 6 , see Table 1) show that faba bean, unlike chickpea, maintains

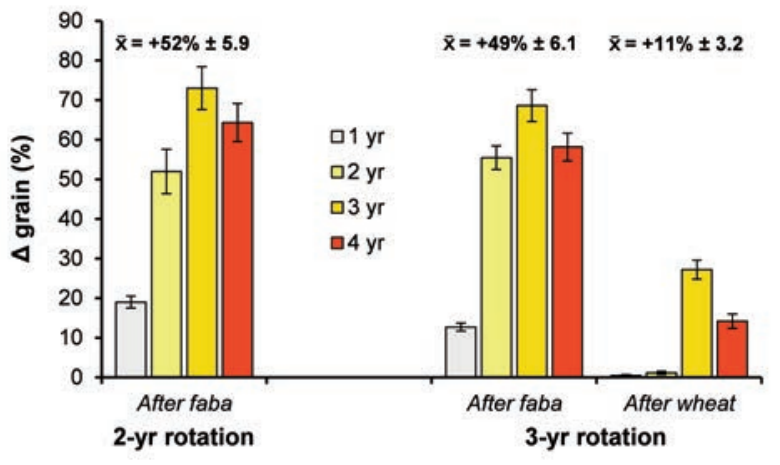

Figure 4. Grain yields of wheat grown under two different crop sequences (2-year rotation: faba bean-wheat, 3-year rotation: faba bean-wheat-wheat. Exp3; Table 1). Data are expressed as percent variation in the grain yield obtained in continuous wheat. The crop sequences were applied continuously for 6 years, and data are from the last 4 years of the experiment. Vertical bars represent \pm standard error.

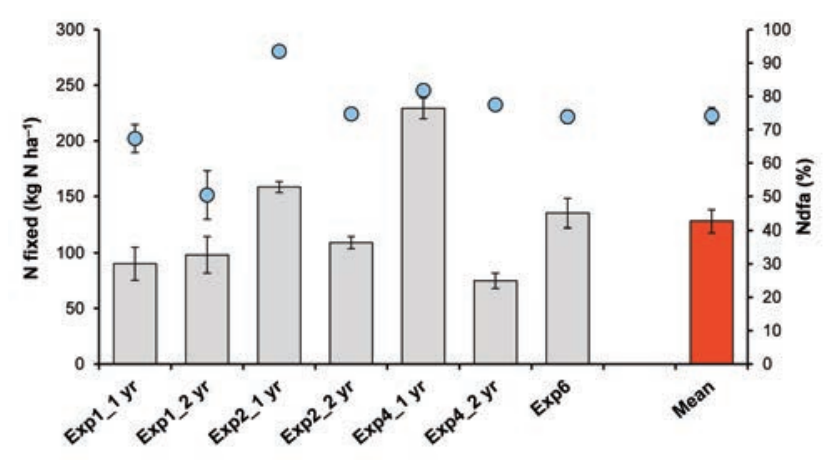

Figure 5. Estimates of the proportion (blue circles) and the amount (grey histograms) of shoot nitrogen fixed by faba bean (Exp1, 2, 4, and 6; Table1). Vertical bars represent \pm standard error. 
a higher dependence on $\mathrm{N}_{2}$ fixation even under high levels of soil mineral N. In fact, levels of soil mineral $\mathrm{N}$ close to $200 \mathrm{~kg} \mathrm{ha}^{-1}$ totally inhibited $\mathrm{N}_{2}$ fixation in chickpea, whereas under the same soil $\mathrm{N}$ supply faba bean still had levels of $\% \mathrm{Ndfa}$ near $50 \%$ (Figure 7A). This result is in line with the findings of Schwenke et al. (1998) and Turpin et al. (2002) for faba bean and chickpea. On the whole, the amount of $\mathrm{N}$ fixed by faba bean increased with the $\mathrm{N}$ supply until $105 \mathrm{~kg} \mathrm{~N} \mathrm{ha}^{-1}$ of soil mineral $\mathrm{N}$ (Figure 7B); further increases in soil mineral $\mathrm{N}$ progressively reduced $\mathrm{N}_{2}$ fixation. A similar trend was observed in chickpea, in which, despite the equal $\mathrm{N}$ supply, the amounts of $\mathrm{N}$ fixed were significantly lower than those recorded in faba bean. However, the increase in soil-avail-
A

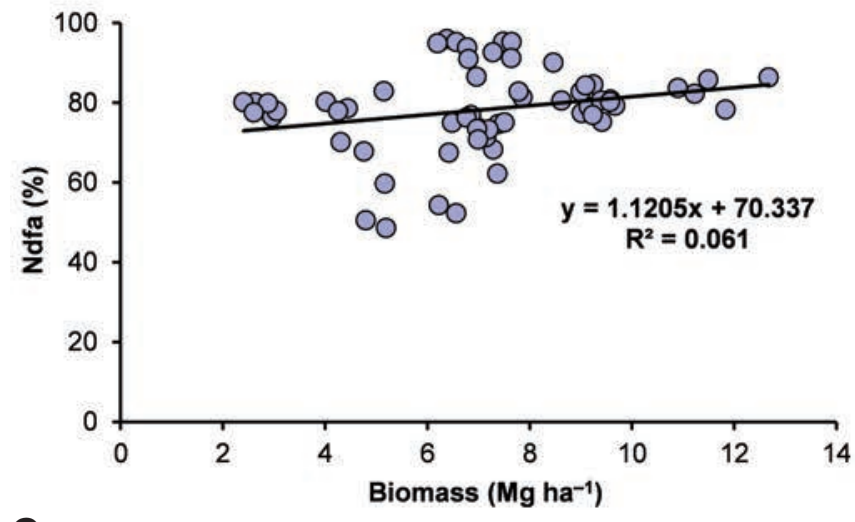

C

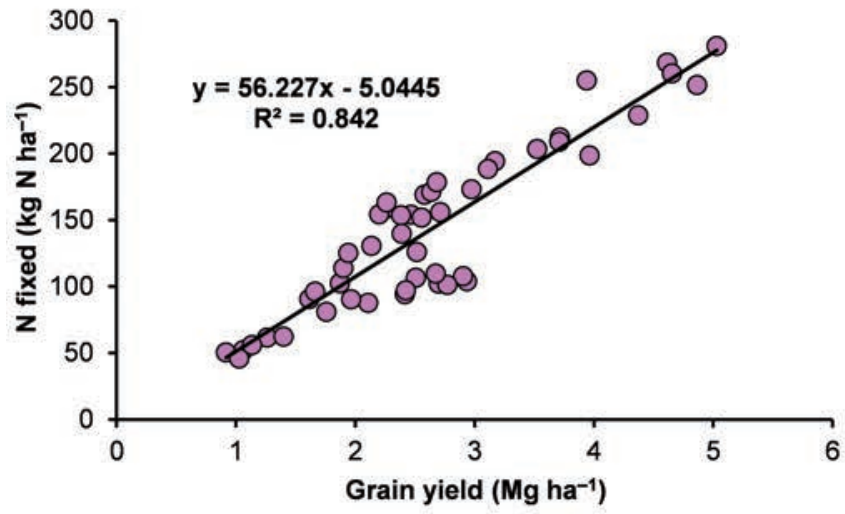

B

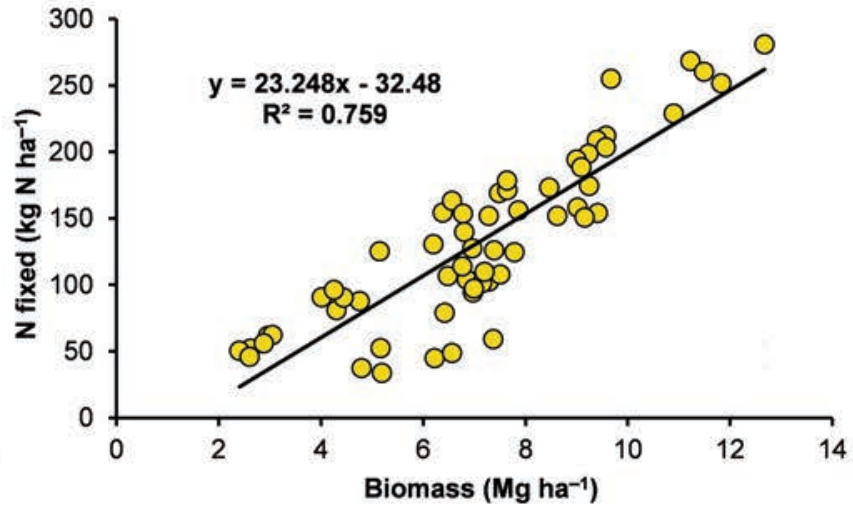

D

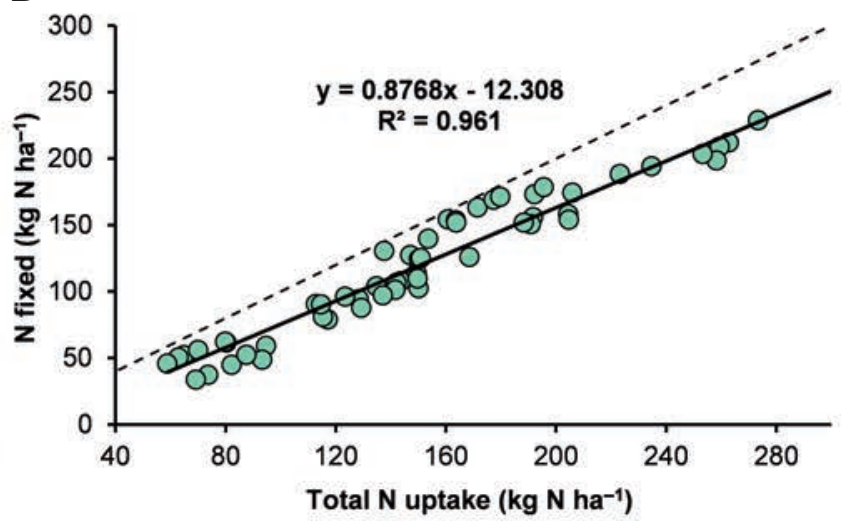

Figure 6. Relationships between the proportion of nitrogen $(\mathrm{N})$ in biomass derived from the atmosphere (Ndfa\%) and faba bean biomass yield (A), the amount of $\mathrm{N}$ fixed in biomass and biomass yield (B), the amount of $\mathrm{N}$ fixed in biomass and grain yield (C), and the amount of $\mathrm{N}$ fixed in biomass and total $\mathrm{N}$ uptake (D) of faba bean. Data obtained from Exp1, 2, 4, and 6 (Table 1). In (D), points on the bisector (dotted line) indicate that all $\mathrm{N}$ accumulated by the plant derived from the atmosphere.

A

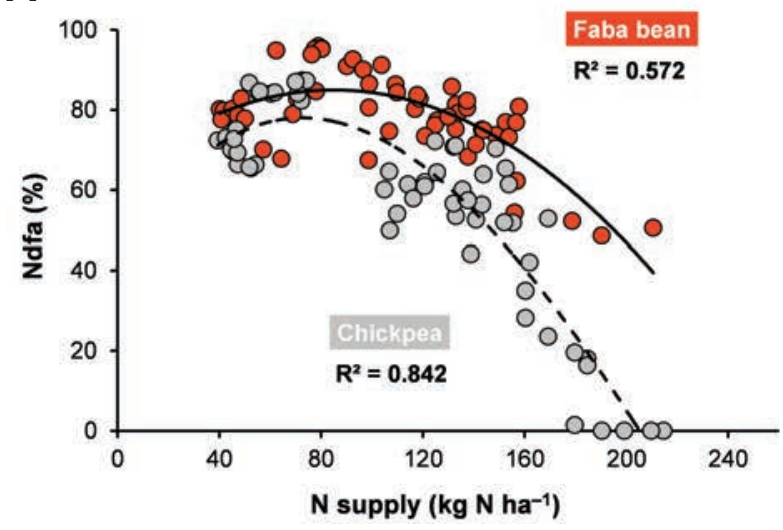

B

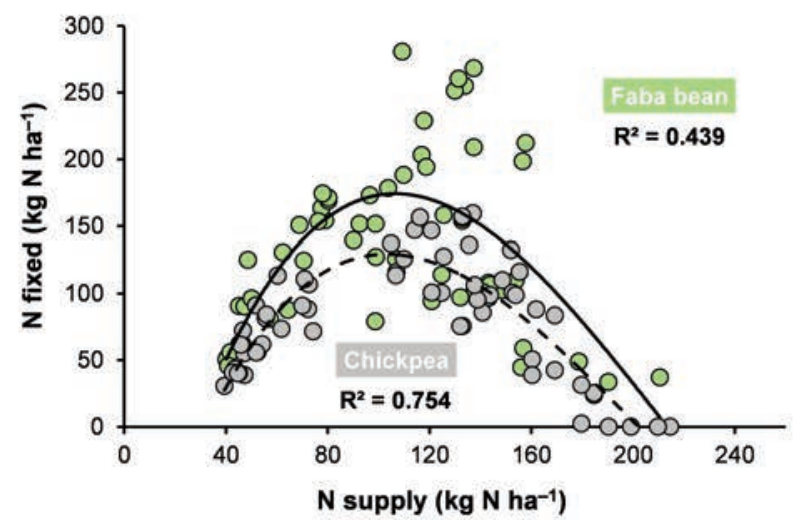

Figure 7. Relationships between the proportion of nitrogen $(\mathrm{N})$ in biomass derived from the atmosphere (Ndfa\%) and soil $\mathrm{N}$ supply (A) and between the amount of $\mathrm{N}$ fixed in biomass and soil $\mathrm{N}$ supply (B). Data obtained from Exp1, 2, 4, 5, and 6 (Table 1). 
able $\mathrm{N}$ is generally attributable to an improvement in edaphic and environmental conditions able to positively influence both soil $\mathrm{N}$ dynamics and plant growth, and consequently plant $\mathrm{N}$ requirements. Therefore, the decreasing effect on $\mathrm{N}_{2}$ fixation caused by the increase in soil mineral $\mathrm{N}$ was, early on, largely offset by the increased $\mathrm{N}$ requirements of plants. Thus, on the basis of our data, the amount of $\mathrm{N}$ fixed by faba bean seems to be increased by strategies capable of ensuring vigorous crop growth (and consequently increasing $\mathrm{N}$ demand) and simultaneously able to reduce soil $\mathrm{N}$ concentration (e.g., growing this legume after an N-hungry crop, as suggested by Peoples et al., 2009).

In order to identify the parameters and define the strategies that can lead to an increase in both $\mathrm{N}_{2}$ fixation and yield in faba bean, it is necessary to understand the seasonal dynamics of $\mathrm{N}$ accumulation and its sources. These issues were addressed in an unpublished 2-year research study (Exp6, see Table 1) whose results suggested that $\mathrm{N}_{2}$ fixation was the main source of $\mathrm{N}$ for faba bean over the entire crop cycle, with values of $\% \mathrm{Ndfa}$ always higher than $65 \%$ (Figure $8 \mathrm{~B}$ ). $\mathrm{N}$ uptake and the amount of $\mathrm{N}$ fixed were relatively low during early growth (0-42 days after sowing), but both increased rapidly after this period and reached their maximum at full flowering (2.5 and $1.6 \mathrm{~kg} \mathrm{~N} \mathrm{ha}^{-1} \mathrm{~d}^{-1}$, respectively, for $\mathrm{N}$ uptake and $\mathrm{N}$ fixed; Figure $8 \mathrm{~A}$ and $\mathrm{B}$ ). After this stage, the rates for both $\mathrm{N}$ uptake and $\mathrm{N}_{2}$ fixation declined slowly, dropping to almost zero after the mid-pod filling stage. The values for both $\mathrm{N}$ uptake rate or $\mathrm{N}$ fixed rate observed in faba bean were markedly higher than the corresponding values observed in chickpea in the early growth stages (from sowing to the end of flowering of faba bean) but lower in the later stages. Significant differences between faba bean and chickpea were also found in the amount of accumulated $\mathrm{N}$ derived from the soil (Ndfs; 46 and $67 \mathrm{~kg} \mathrm{~N} \mathrm{ha}^{-1}$ for faba bean and chickpea, respectively; Figure 8C). On the whole, these data suggest that faba bean is less able, compared to chickpea (and compared to the reference crop, which in this case was durum wheat; data not shown), to utilise the mineral $\mathrm{N}$ available in soil. Other studies have highlighted the fact that faba bean is less efficient in recovering $\mathrm{N}$ from the soil than other grain legumes and cereals, relating this result to the lower plant populations of faba bean (Rennie and Dubetz, 1986; Smith et al., 1987; Jensen et al., 2010). We hypothesise other plausible explanations for these differences. First, these species may have a different root exploration capacity. Chickpea has a deeper and a more expanded root system than faba bean (Gregory, 1988), which can allow chickpea to access $\mathrm{N}$ resources not available to faba bean. Second, but no less important, is that these differences could be related to the different patterns of plant growth and $\mathrm{N}$ uptake between the two species, with faba bean markedly earlier than chickpea. We have observed that faba bean has rapid early growth (faster than other legume species), and in this growth phase it efficiently utilises the soil $\mathrm{N}$ available (more than chickpea); moreover, its $\mathrm{N}$ demand is very high during flowering (at the end of this stage this crop has already accumulated more than $70 \%$ of its $\mathrm{N}$ requirement). In the Mediterranean environment, the flowering of faba bean falls between the end of winter and the beginning of spring, when the soil $\mathrm{N}$ available is still low because of the low rate of mineralisation of soil organic matter (as temperatures are not optimal for this process). In these conditions, faba bean must increase the $\mathrm{N}_{2}$ fixation process to satisfy its $\mathrm{N}$ needs; this makes the crop inefficient at utilising later available $\mathrm{N}$. Therefore, our data suggest that the poor ability of faba bean to absorb mineral $\mathrm{N}$ from the soil is related to asynchrony between plant $\mathrm{N}$ demand and $\mathrm{N}$ availability in the soil. In contrast, chickpea showed little ability to utilise available soil $\mathrm{N}$ during the early growth stage (at that time, its growth rate and thus its $\mathrm{N}$ demand were both rather limited), whereas it was extremely efficient at utilising later soil $\mathrm{N}$ (comparable to the reference crop; data not shown) that became available when the $\mathrm{N}$ demand by the crop was at its maximum. Clearly, these patterns of soil $\mathrm{N}$ utilisation, so different between faba bean and chickpea, open up for each crop time slots in which the environmental release of soil $\mathrm{N}$ not taken up by
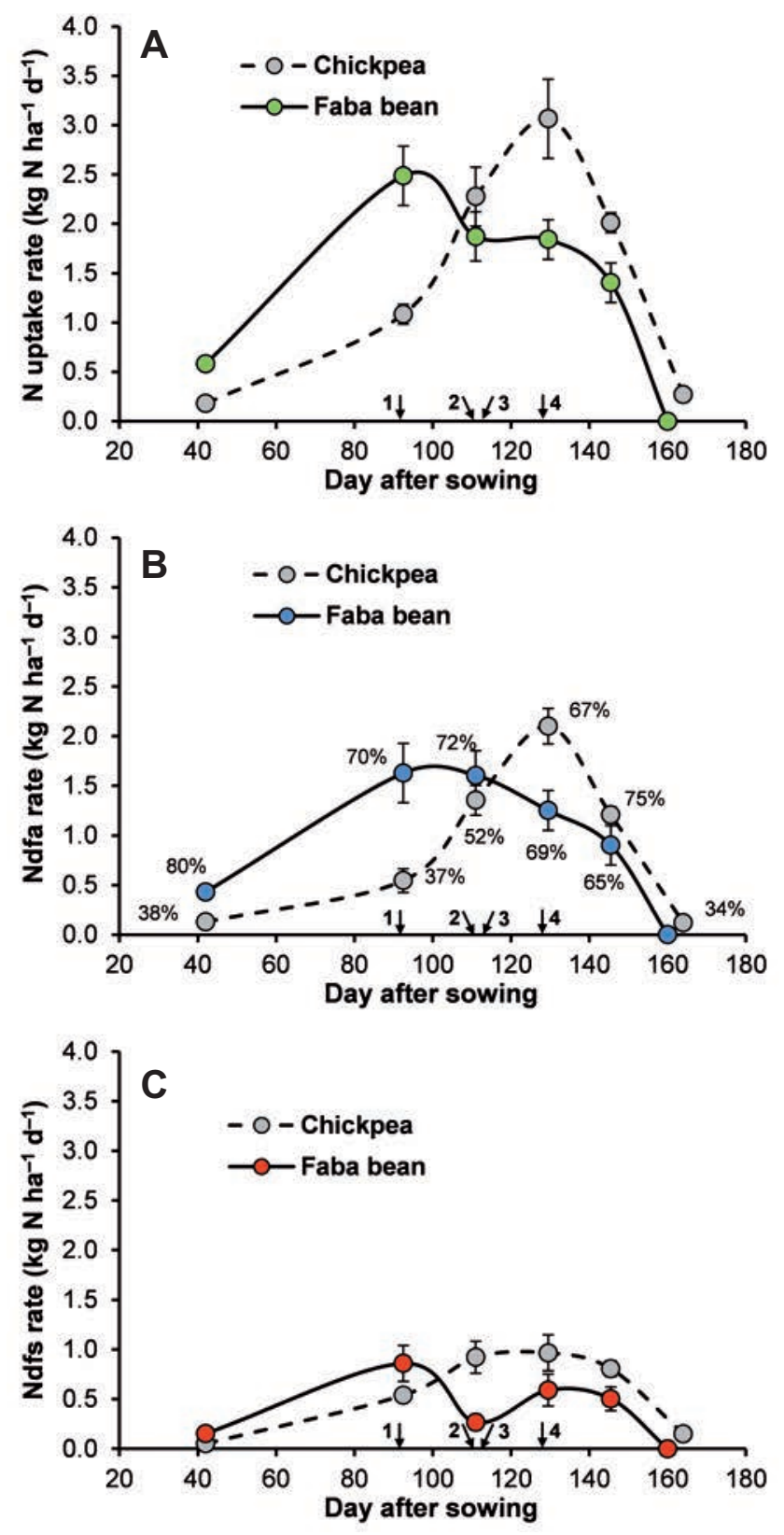

Figure 8. Trends in rates of nitrogen $(\mathrm{N})$ uptake $(\mathrm{A}), \mathrm{N}$ derived from the atmosphere (Ndfa; $B$ ), and $\mathrm{N}$ derived from the soil (Ndfs; C) for faba bean (colored circles) and chickpea (grey circles) over the crop cycle. Vertical bars represent \pm standard error. Data are means of 2 years (Exp6; Table 1). 1 and 2 indicate the dates of the beginning of flowering of faba bean and chickpea, respectively; 3 and 4 indicate the dates of the end of flowering of faba bean and chickpea, respectively. In (B), percentage values at each point indicate the proportion of legume $\mathrm{N}$ derived from $\mathrm{N}_{2}$ fixation. 
the crop becomes more probable (via leaching during the winter season for chickpea or volatilisation and denitrification during the spring for faba bean).

The different abilities of faba bean and chickpea to recover soil inorganic $\mathrm{N}$ during the growing season surely contribute to explaining the greater levels of soil inorganic $\mathrm{N}$ at harvest $(\mathrm{N}$ sparing) after faba bean compared to chickpea (or durum wheat) that we observed in many experiments (Exp2, 4, and 6, see Table 1) carried out in the past two decades (Figure 9). On average, the $\mathrm{N}$ spared (calculated on the $0-0.40 \mathrm{~m}$ soil layer) by faba bean was 28 $\mathrm{kg} \mathrm{N} \mathrm{ha}{ }^{-1}$, whereas chickpea and wheat left essentially the same amount of residual $\mathrm{N}$ in the soil (19 and $17 \mathrm{~kg} \mathrm{~N} \mathrm{ha}^{-1}$, respectively). Spared $\mathrm{N}$ can contribute significantly to the $\mathrm{N}$ benefits measured in the succeeding crop, as shown in many experiments (e.g., Chalk et al., 1993). However, in the Mediterranean environment, considering both the long period of fallow between the harvest of the legume crop and the sowing of the succeeding cereal (5-6 months) and the distribution of rain (which is often abundant during the autumn), inorganic spared $\mathrm{N}$ could be partially lost, with a potentially harmful impact on the environment.

\section{Symbiotic nitrogen fixation and agronomic management: tillage, intercropping, and mycor- rhizal inoculation}

Besides environmental conditions (temperature, soil type, etc.), symbiotic $\mathrm{N}_{2}$ fixation can be influenced by agronomic management practices, as reviewed by van Kessel and Hartley (2000). In Figure 10 we report results from different experiments (Exp1 and 2, Table 1) we carried out on $\mathrm{N}$ uptake and $\mathrm{N}_{2}$ fixation in faba bean grown under two different soil tillage systems: conventional tillage (CT; moldboard plowing followed by shallow harrowing operations) and no tillage (NT). NT resulted, on average, in an increase in the amount of $\mathrm{N}$ fixed by faba bean $\left(+22 \mathrm{~kg} \mathrm{~N} \mathrm{ha}^{-1}\right)$. This result is mainly attributable to an increase in the demand for $\mathrm{N}$ by the legume crop, as $\mathrm{N}$ uptake increased from $157 \mathrm{~kg} \mathrm{~N} \mathrm{ha}^{-1}$ in CT to $172 \mathrm{~kg} \mathrm{~N} \mathrm{ha}^{-1}$ in NT (Figure 10). Many long-term researches have highlighted the fact that in the Mediterranean environment the continuous application of NT often influences positively both crop growth and yield by improving soil fertility (increasing soil water storage, increasing soil organic matter and biodiversity, enhancing aggregation and aggregate stability, etc.; López-Bellido et al., 1996; Hernanz et al., 2002). This suggests that plant $\mathrm{N}$ demand increases under NT with respect to CT; consequently, to satisfy their augmented $\mathrm{N}$ needs, legume plants under NT respond by increasing their reliance on $\mathrm{N}_{2}$ fixation. This was indeed observed in our trials, in which the $\%$ Ndfa increased from $69 \%$ in CT to $76 \%$ in NT. Obviously, the advantages of NT over CT do not always materialise. Rather, many times NT has no effect or, in some cases, can impair crop growth and productivity. Therefore, it is not surprising that some studies (e.g., Ruisi et al., 2012) have reported no influence of tillage system on faba bean $\mathrm{N}_{2}$ fixation in terms of either the percentage or amount of $\mathrm{N}$ fixed. Moreover, the advantage of NT over CT in terms of $\mathrm{N}_{2}$ fixation could also be partly attributable to the fact that when tillage is minimised, rates of mineralisation and nitrification are reduced, with a consequent decrease in soil $\mathrm{N}$ availability and consequently an increase in dependence on $\mathrm{N}_{2}$ fixation. The latter factor (the lower soil N availability in NT than CT) likely played a significant role in our experiments, as we observed an average increase in $\mathrm{N}$ fixed in NT compared to CT that was higher than that recorded for $\mathrm{N}$ uptake.
Intercropping legumes and non-legumes can increase $\mathrm{N}_{2}$ fixation, increasing the opportunity for $\mathrm{N}$ use complementarity (van Kessel and Hartley, 2000). The non-legume crop utilises most of the available soil $\mathrm{N}$, as it is generally much more competitive than the legume and much more able to absorb this element. However, this $\mathrm{N}$ depletion does not have negative repercussions for the legume crop, which is able to satisfy its $\mathrm{N}$ needs by increasing $\mathrm{N}_{2}$ fixation. This results in an overall improvement in $\mathrm{N}$ use efficiency with positive repercussions from an environmental point of view, so that crop diversification in space is considered an appropriate tool for developing more sustainable agriculture systems (Köpke and Nemecek, 2010). However, the amount of $\mathrm{N}$ fixed by a legume in intercropped systems is often lower than that fixed by the

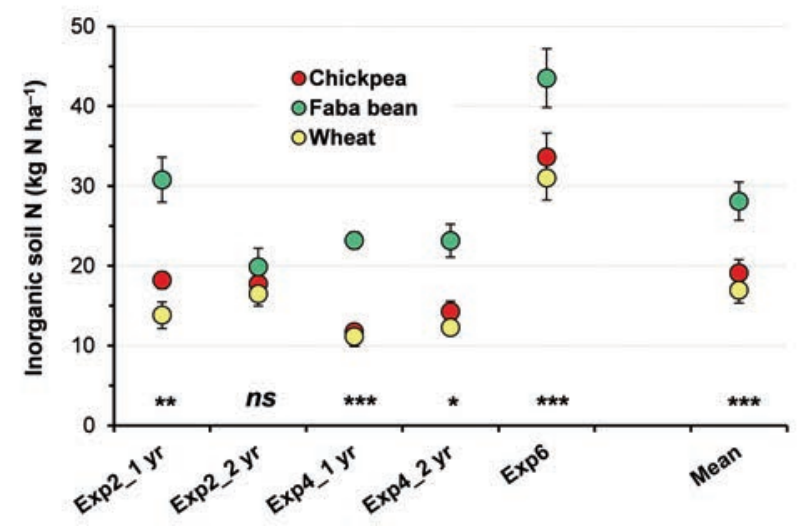

Figure 9. Soil inorganic nitrogen $(\mathrm{N})$ at the harvest of faba bean (green circles), chickpea (red circles), and wheat (yellow circles) (Exp2, 4, and 6; Table 1). Vertical bars represent \pm standard error. For each experiment, ${ }^{*}{ }^{* *}$, and ${ }^{* * *}$ denote significant differences between faba bean and both chickpea and wheat at $P \leq 0.05$, $P \leq 0.01$, and $P \leq 0.001$, respectively; ns, not significant at $P \leq 0.05$.

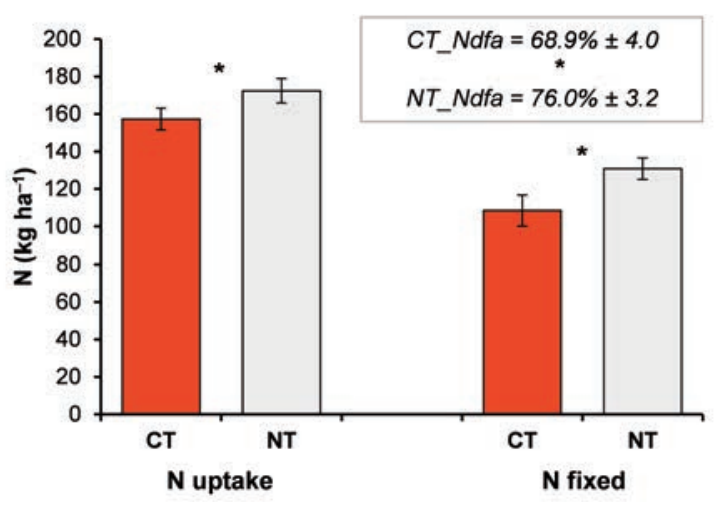

Figure 10. Nitrogen $(\mathrm{N})$ uptake and $\mathrm{N}$ fixed by faba bean under different soil tillage techniques: $\mathrm{CT}$, conventional tillage; NT, no tillage (Exp1 and 2; Table 1). The percentage of $\mathrm{N}$ derived from the atmosphere (Ndfa) observed under the two tillage techniques is also reported (in the box). Vertical bars represent \pm standard error. $N=22$. For each trait, the asterisk denotes significant differences between CT and NT at $\mathrm{P} \leq 0.05$. 
monocrop, generally because of the lower density of the legume plant and increased competition for resources (nutrients, water, light) with the non-legume crop.

We performed a pot experiment (Exp8, see Table 1) in which faba bean was grown alone or intercropped with durum wheat in the presence or absence of mycorrhizal inoculum. The results were totally in agreement with what was just asserted: the percentage of Ndfa (measured at the early flowering stage) increased from $24 \%$ to $54 \%$ (in monocropped and intercropped faba bean, respectively) but with a reduction in the amount of $\mathrm{N}$ fixed beyond $50 \%$ (data not shown). Another advantage of intercropping is that $\mathrm{N}$ can be transferred from the legume to the associated non-legume crop. This can occur through several pathways: root $\mathrm{N}$ exudates, decomposition of legume tissues or nodules, arbuscular mycorrhizal (AM) fungi that can link the roots of the intercropped species. It is widely recognised that $\mathrm{N}$ transfer between plants is difficult to quantify, and it is even more difficult to obtain accurate information on the relative importance of the different pathways of $\mathrm{N}$ transfer (Høgh-Jensen, 2006; Chalk et al., 2014). In the aforementioned pot experiment (Exp8), we estimated $\mathrm{N}$ transfer by labelling the faba bean's absorption of a ${ }^{15} \mathrm{~N}$-enriched solution via the stem. In the mycorrhizal treatment the amount of $\mathrm{N}$ transferred by faba bean to the associated durum wheat was estimated to be about $4 \%$ of the $\mathrm{N}$ accumulated in the legume crop, whereas in the non-mycorrhizal treatment the $\mathrm{N}$ transfer was negligible (data not shown). This suggests that AM fungi played an important role in the exchange of $\mathrm{N}$ between companion crops. Our results also showed that AM fungi positively influenced the percentage of $\mathrm{N}$ fixation (measured at the early flowering stage) in the intercropped faba bean (from $49 \%$ to $61 \%$ ) but not when the legume was grown alone ( $24 \%$ on average; data not shown). Several studies have shown that AM symbiosis improves plant growth and nutrient uptake, particularly when plants are grown under nutrient-limiting conditions (Saia et al., 2014). In our experiment, faba bean grown alone likely had access to sufficient amounts of nutrients to meet its needs and thus did not benefit from symbiosis with AM fungi. In contrast, in the intercropped system, the highly competitive nonlegume component depleted nutrients from the soil, thus increasing the dependence/interest of the faba bean on activating mycorrhizal symbiosis to satisfy its needs. Clearly, many other agronomic factors (e.g., genotype, inoculum, sowing time and density, fertilisation, weed control strategy) influencing both crop growth and $\mathrm{N}$ soil availability can have a significant impact on the $\mathrm{N}_{2}$ fixation process. Many of these factors require investigation to enhance the role that faba bean can play in cropping systems in order to increase the sustainability of production processes.

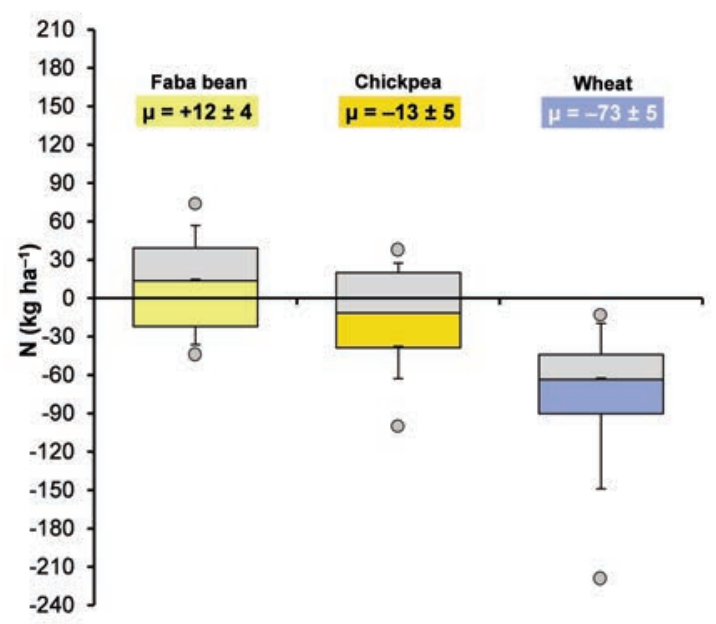

Figure 11. Nitrogen $(\mathrm{N})$ balance of faba bean $(\operatorname{Exp} 1,2,4$, and 6; Table 1), chickpea (Exp2, 4, 5, and 6; Table 1), and wheat (Exp1, 2, 4, 5, and 6; Table 1) calculated as the difference between the amount of $\mathrm{N}$ fixed and the amount of $\mathrm{N}$ in grain. Box plots represent $50 \%$ of the data; the line in the box represents the median. Whiskers represent the $\mathbf{1 0}^{\text {th }}$ and $90^{\text {th }}$ percentiles. Symbols represent outliers (extreme values). $\mathrm{N}=60,54$, and 104 for faba bean, chickpea, and wheat, respectively.

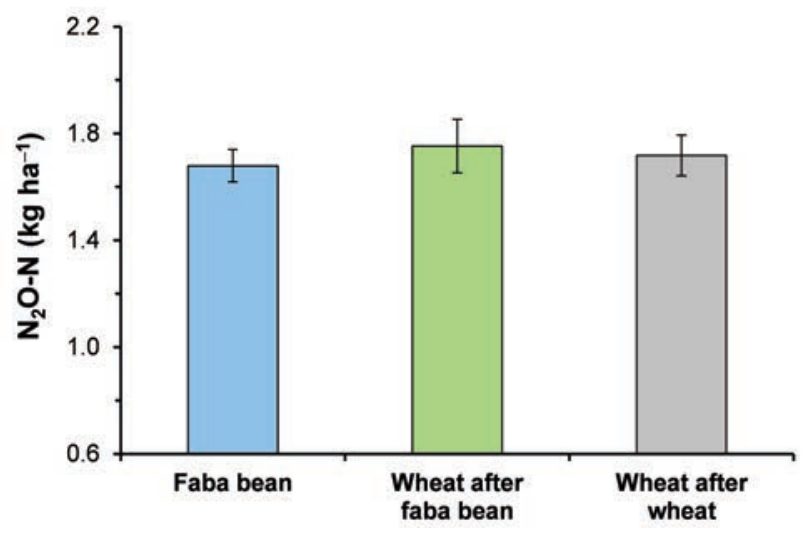

Figure 12. Total $\mathrm{N}_{2} \mathrm{O}$-nitrogen emissions from soils during the cropping season (data obtained from a 2-year study within the framework of Exp1 after 22 years of continuous application of the treatments; Table 1). Data are means of 2 years. Vertical bars represent \pm standard error. $N=12$. No significant differences were found among the crops at $\mathrm{P} \leq 0.05$.

Table 2. The impact of different crops on nitrogen dynamics in the subsequent season through a comparison of the amounts of nitrogen accumulated by a wheat crop (Exp7; Table 1).

\begin{tabular}{|c|c|c|c|c|}
\hline & Faba bean-Wheat & Chickpea-Wheat & Pea-Wheat & Wheat-Wheat \\
\hline Residue $\mathrm{N}$ from biomass* $\left(\mathrm{kg} \mathrm{N} \mathrm{ha}^{-1}\right)$ & $76 \pm 4.2^{\mathrm{a}}$ & $69 \pm 3.6^{\mathrm{ab}}$ & $52 \pm 2.2^{\mathrm{bc}}$ & $42 \pm 1.0^{c}$ \\
\hline Total $\mathrm{N}$ uptake of wheat $\left(\mathrm{kg} \mathrm{N} \mathrm{ha}^{-1}\right)$ & $159 \pm 6.5^{\mathrm{a}}$ & $151 \pm 7.1^{\mathrm{ab}}$ & $146 \pm 4.8^{b}$ & $117 \pm 3.8^{c}$ \\
\hline Wheat $\mathrm{N}$ benefit from legume ${ }^{\circ}\left(\mathrm{kg} \mathrm{N} \mathrm{ha}^{-1}\right)$ & $42^{\mathrm{a}}$ & $34^{\mathrm{ab}}$ & $29 \mathrm{~b}$ & - \\
\hline Apparent recovery of legume $\mathrm{N}^{\#}(\%)$ & $64^{\mathrm{a}}$ & $49^{\mathrm{b}}$ & $56^{\mathrm{ab}}$ & - \\
\hline Fertiliser $\mathrm{N}$ equivalent ${ }^{\S}\left(\mathrm{kg} \mathrm{N} \mathrm{ha}^{-1}\right)$ & $64^{\mathrm{a}}$ & $57^{\mathrm{ab}}$ & $48^{\mathrm{b}}$ & - \\
\hline
\end{tabular}

$\mathrm{N}$, nitrogen. *Includes $\mathrm{N}$ in straw after grain harvest plus an estimate of belowground $\mathrm{N} ;{ }^{\circ}$ calculated as ( $\mathrm{N}$ uptake of wheat after legume) - (N uptake of wheat after wheat); \#calculated for each legume as (Wheat $\mathrm{N}$ benefit)/(Residue $\mathrm{N}$ from biomass) $\times 100$; \$the amount of fertiliser $\mathrm{N}$ that is necessary to provide wheat grown after wheat to obtain the same yield of no $\mathrm{N}$ fertilised wheat grown after legume. Data are means of 2 years. For each trait, different letters denote significant differences among the crop sequences at $\mathrm{P}<0.05$. 


\section{Nitrogen balance}

Cultivating a grain legume crop increases the soil $\mathrm{N}$ pool only when the amount of $\mathrm{N}$ fixed by the legume is greater than the amount of $\mathrm{N}$ removed with grain and/or residues. In other words, the $\mathrm{N}$ balance is positive only when $\% \mathrm{Ndfa}$ values are higher than those of the nitrogen harvest index (NHI). Clearly, the legume contribution to the soil $\mathrm{N}$ pool should be increased through an increase in $\mathrm{N}_{2}$ fixation and not a reduction in NHI, as low NHI values underlie low plant production and poor quality.

Data from our studies (Exp1, 2, 4, 5, and 6, Table 1) showed that faba bean had a positive $\mathrm{N}$ balance $\left(+12 \mathrm{~kg} \mathrm{~N} \mathrm{ha}^{-1}\right.$ on average; Figure 11) but with consistent variation (range: -44 to $+73 \mathrm{~kg} \mathrm{~N}$ $\mathrm{ha}^{-1}$ ) site by site and year by year. However, we have seen that soil and climatic conditions have a strong influence on plant growth, grain yield, and $\mathrm{N}_{2}$ fixation. Although the contribution of faba bean to the soil $\mathrm{N}$ pool could appear poor, it is markedly higher than that found in other grain legumes grown under the same conditions (chickpea: Figure 11; lentil and pea: see Figure 4 in Ruisi et al., 2012). This result must be due more to the greater dependence of faba bean than the other grain legumes on $\mathrm{N}_{2}$ fixation than to differences in NHI. The results of our research on $\mathrm{N}$ balance are in agreement with those of other authors (Walley et al., 2007; Hauggaard-Nielsen et al., 2009) who compared several grain legumes (chickpea, common bean, faba bean, lentil, etc.).

In any case, the $\mathrm{N}$ balance, as it is generally calculated, ignores $\mathrm{N}$ rhizodeposition (which includes root exudates and root tissues and nodules that decompose during the crop cycle and after the crop harvest), thus leading to an underestimation of the contribution of the legume to the soil $\mathrm{N}$ pool. Some studies have shown that the contribution of faba bean belowground $\mathrm{N}$ may represent from $15 \%$ to $40 \%$ of total plant N (as reviewed by Jensen et al., 2010); this has been calculated to be up to $100 \mathrm{~kg} \mathrm{~N} \mathrm{ha}^{-1}$ of additional $\mathrm{N}$ deposited in the soil, thus improving consistently the soil $\mathrm{N}$ balance and representing an important source of $\mathrm{N}$ for subsequent crops. However, it must be highlighted that the efficiency of use of $\mathrm{N}$ in the legume residues (both below and above ground) depends on many factors, including the length of time between harvesting of the legume and sowing of the subsequent crop, legume crop residue management, soil tillage management, the rate of organic matter mineralisation, climatic conditions, and the degree of synchrony between the release of mineral $\mathrm{N}$ from residues and the timing of requirements for $\mathrm{N}$ of the subsequent crop (Crews and Peoples, 2005). Clearly, the more the $\mathrm{N}$ from residues is not used by the crop, the greater the potential for $\mathrm{N}$ losses due to leaching, denitrification, and volatilisation.

The fate of the $\mathrm{N}$ in the residues of legume species, including faba bean, has often been monitored through ${ }^{15} \mathrm{~N}$-labeled residues. Several studies have shown that generally less than $30 \%$ of the $\mathrm{N}$ in legume residues is used by the subsequent crop (generally a cereal) and that this amount of $\mathrm{N}$ represents a small portion (often $<10 \%$ ) of the total amount of $\mathrm{N}$ accumulated by the subsequent crop (Peoples et al., 2009). However, the ${ }^{15} \mathrm{~N}$-labeled residues method leads to an underestimation of the contribution of the legume species to the total amount of $\mathrm{N}$ accumulated by the subsequent crop, as a considerable part of the ${ }^{15} \mathrm{~N}$ supplied through the legume residues is immobilised by soil microorganisms and, at the same time, unlabeled $\mathrm{N}$ (through the mineralisation of older soil organic $\mathrm{N}$ ) is made available for crops ( $\mathrm{N}$ pool substitution; Peoples et al., 2009).

A 2-year study (Exp7, see Table 1) we performed to evaluate the benefits of several legumes on the $\mathrm{N}$ uptake of a subsequent wheat crop seems to corroborate this hypothesis. Data showed an apparent recovery of faba bean $\mathrm{N}$ higher than $60 \%$ and a contribution of faba bean $\mathrm{N}$ to the total amount of $\mathrm{N}$ accumulated by the cereal of about $30 \%$ (Table 2). Furthermore, the values observed for faba bean were significantly higher than those observed for both chickpea and pea. We presume that the differences among the legume species are attributable to the different compositions of the crop residues $(\mathrm{C} / \mathrm{N}$ ratio, content of lignin and other components, etc.) able to influence the rapidity of their degradation by microorganisms in the soil. Moreover, in the same study the $\mathrm{N}$ benefits of including faba bean in the cropping system were quantified in about $65 \mathrm{~kg} \mathrm{ha}^{-1}$ of $\mathrm{N}$ fertiliser, a result that further emphasises the positive role of faba bean in reducing $\mathrm{N}$ inputs for subsequent crops and consequently mitigating the impact of agriculture on the environment. Considering the importance of this issue, further research is needed to evaluate the benefits from these and other legume species in other environments, due to probable species $\times$ environment interaction.

\section{Nitrogen gaseous emissions}

There is much debate over the effects of growing legumes on the extent of $\mathrm{N}$ gaseous emissions. On the one hand, it can be assumed that the increase in soil $\mathrm{N}$ availability generated by the presence of a legume in the cropping system can lead to increased risks of environmental release of this element; on the other hand, only a few experiments have confirmed this hypothesis (Rochette and Janzen, 2005; Senbayram et al., 2016). In contrast, many studies have shown that gaseous $\mathrm{N}$ losses during the growing season are lower for annual legumes than for annual non-legume crops. In a review using data from 71 site-years, Jensen et al. (2012) highlighted the fact that soils under legumes emitted a total of $1.29 \mathrm{~kg}$ $\mathrm{N}_{2} \mathrm{O}-\mathrm{N} \mathrm{ha}{ }^{-1}$ during a growing season, a value markedly lower than that observed for soils under $\mathrm{N}$-fertilised crops $\left(3.22 \mathrm{~kg} \mathrm{~N}_{2} \mathrm{O}-\mathrm{N} \mathrm{ha}^{-1}\right)$ and very similar to that observed for soils left unplanted or soils under unfertilised non-legume crops (1.20 kg $\mathrm{N}_{2} \mathrm{O}-\mathrm{N} \mathrm{ha}{ }^{-1}$ ). However, it is noteworthy that most of the studies published to date on this topic have been carried out in temperate climate regions, often using soybean as the legume crop. To date, very little research has been conducted in Mediterranean conditions to estimate the $\mathrm{N}_{2} \mathrm{O}$ flux from legume crops typically grown in this environment, such as faba bean. Therefore, we conducted a 2-year study within the framework of Exp1 (an ongoing long-term trial started in 1992; see Table 1) whose data are summarised in Figure 12. On average, no differences were found in $\mathrm{N}_{2} \mathrm{O}-\mathrm{N}$ emissions during the growing season between faba bean and continuous wheat or wheat grown after faba bean, in agreement with the findings on lupine in Australia (Barton et al., 2011) and common bean in Mali (Dick et al., 2008). Since no N-fertiliser was applied to faba bean (whereas 80 and $120 \mathrm{~kg} \mathrm{ha}^{-1}$ of mineral $\mathrm{N}$ were applied, respectively, to wheat grown after faba bean and to continuous wheat), hence the lack of differences among the three crops for $\mathrm{N}_{2} \mathrm{O}$ fluxes are probably to be connected to the $\mathrm{N}$ rhizodeposition of faba bean during the crop cycle, as also suggested by Rochette and Janzen (2005). In addition, we hypothesise that a considerable contribution could derive from the moderate ability of faba bean to utilise mineral $\mathrm{N}$ in the soil. In fact, both mechanisms lead to an increase in $\mathrm{NO}_{3}^{-}$available for potential denitrification losses. Moreover, $\mathrm{N}$ losses through volatilisation (i.e., $\mathrm{NH}_{3}-\mathrm{N}$ emissions) were also monitored in the same 2-year experiment. These $\mathrm{N}$ losses were markedly lower in soils under faba bean compared to 
wheat, and in this latter crop they varied widely in relation to the amount of $\mathrm{N}$ fertiliser applied (data not shown). Thus, it is evident that introducing faba bean into the cropping system allows for a consistent reduction in the use of $\mathrm{N}$ fertilisers, which in turn results in reduced emission of $\mathrm{NH}_{3}$ and thus a reduction in the impact of production processes on the environment.

A

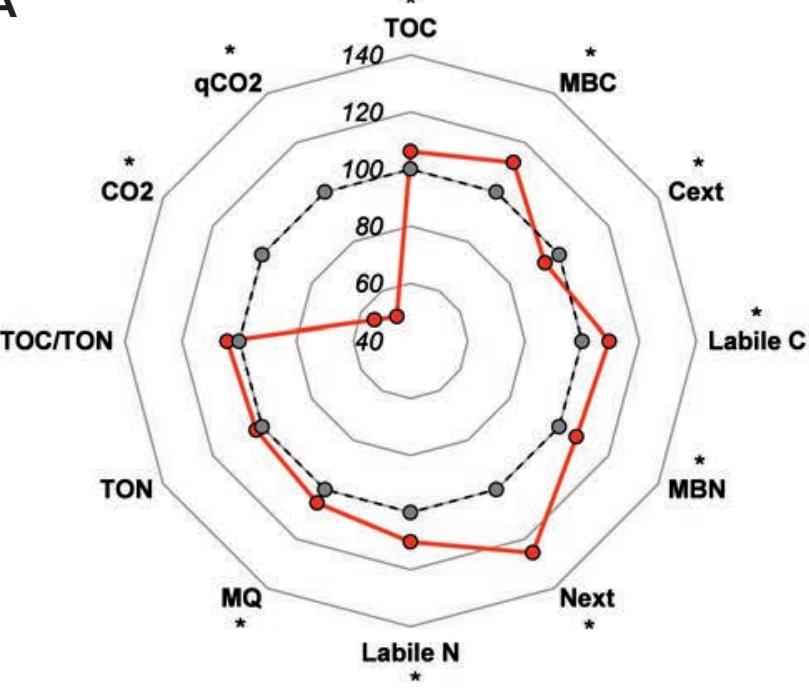

\section{Rotational benefits not related to nitrogen}

As previously mentioned, the introduction of a legume such as faba bean into a cropping system can provide, besides the aforementioned N-related benefits, a range of other potential benefits, such as improvements in the physical, chemical, and biological

B

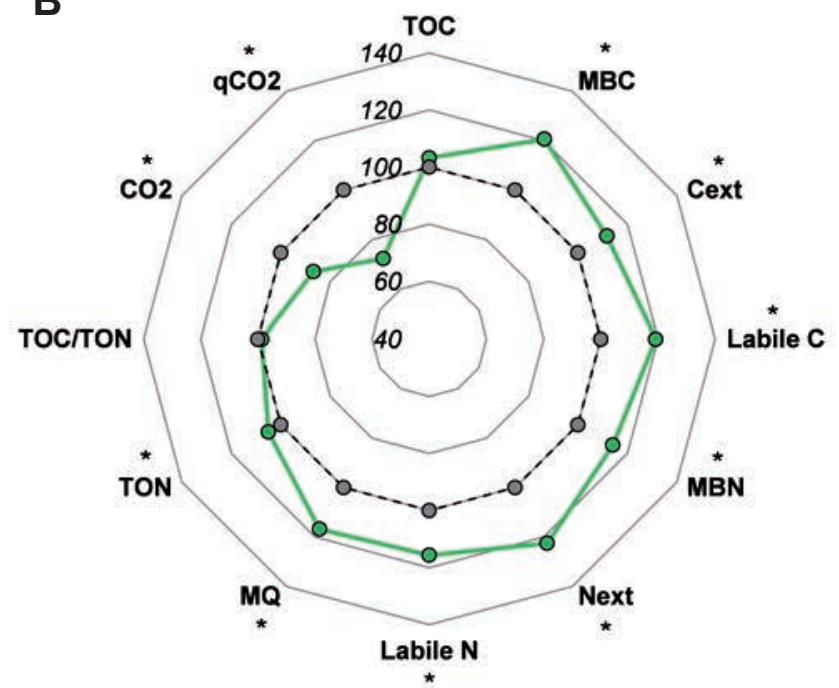

Figure 13. Chemical and biological properties of soils after 22 years of continuous application of different crop sequences: wheat-wheat (dotted line, gray symbols) or faba bean-wheat (solid line, colored symbols) (data obtained from a 1-yr in-depth study within the framework of Exp1; Table 1). Analyses were done separately for two soil layers: (A) 0-15 cm and (B) 15-30 cm. Data are means of 3 measurements done before sowing, at wheat heading, and at wheat harvest. Results are presented relative to a wheat-wheat crop sequence $(=100 \%$; dotted lines). For each trait, the presence of asterisk denotes significant differences between conventional tillage and no tillage at $\mathrm{P} \leq \mathbf{0 . 0 5}$. TOC=total organic $\mathrm{C} ; \mathrm{MBC}=$ microbial biomass $\mathrm{C}$; Cext=extractable $\mathrm{C} ; \mathrm{MBN}=$ microbial biomass $\mathrm{N}$; Next=extractable N; $\mathrm{MQ}=$ microbial quotient; $\mathrm{TON}=$ total organic $\mathrm{N} ; \mathrm{CO} 2=$ basal respiration; $\mathrm{qCO} 2=$ metabolic quotient.

A

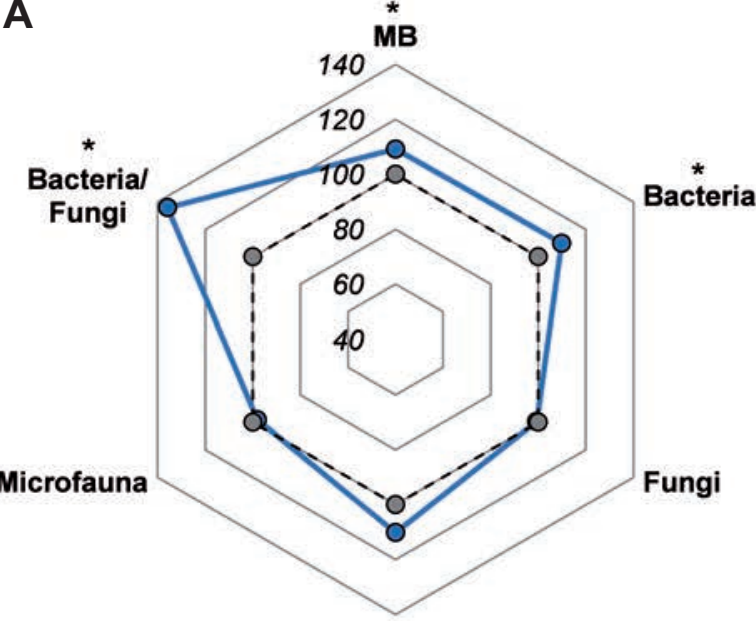

AMF *
B

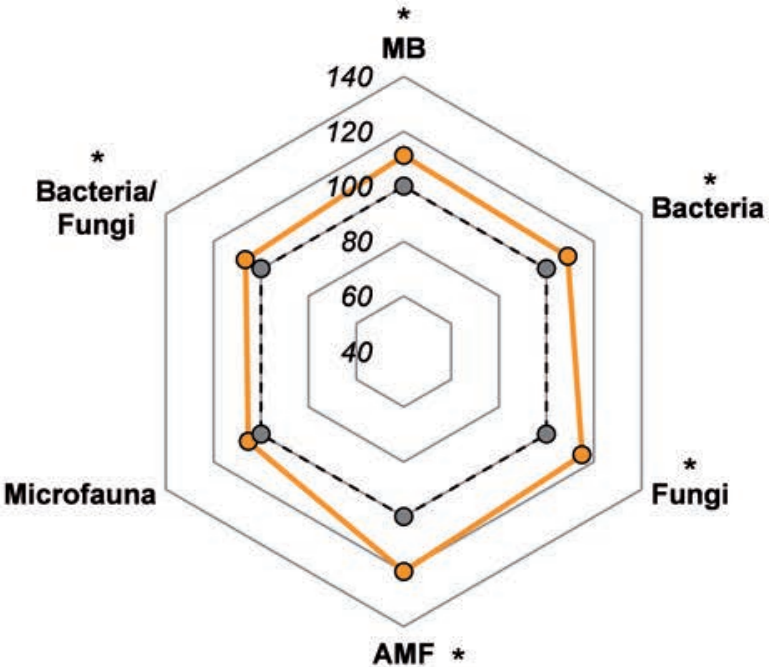

Figure 14. Structure of the microbial community in plowed soils after 22 years of continuous application of different crop sequences: wheat-wheat (dotted line, gray symbols) or faba bean-wheat (solid line, colored symbols) (data obtained from a 1-yr in-depth study within the framework of Exp1; see Table 1). Analyses were done separately for two soil layers: (A) $0-15 \mathrm{~cm}$ and (B) $15-30 \mathrm{~cm}$. Data are means of 3 measurements done before sowing, at wheat heading, and at wheat harvest. Results are presented relative to a wheat-wheat crop sequence $(=100 \%$; dotted lines). For each trait, the presence of asterisk denotes significant differences between conventional tillage and no tillage at $\mathrm{P} \leq \mathbf{0 . 0 5}$. MB=microbial biomass; $\mathrm{AMF}=$ arbuscular mycorrhizal fungi. 
properties of the soil and reductions in weeds, diseases, and pests (Rochester et al., 2001; Kirkegaard et al., 2008; Peoples et al., 2009; Jensen et al., 2010). It is well known that, similar to what happens in natural ecosystems, the greater the increase in biodiversity (achievable through an increase in the number of species present in the cropping system), the greater the increase in crop yield and stability. However, the results of studies carried out to evaluate the effects of different cropping systems (with or without legume species) on the physical, chemical, and biological characteristics of soil (most of which have been conducted in temperate regions) are often contradictory, reporting in some cases benefits but in other cases null or even negative effects (McDaniel et al., 2014; Tienmann et al., 2015). This discrepancy can be attributable to several factors: variability in the duration of the experiments, differences in the species and crop sequences investigated, variability in the agronomic techniques adopted (fertilisation, crop residue management, etc.), or differences in the pedo-climatic characteristics of the experimental sites.

Data (still not published) obtained from a study performed within the framework of Exp1 (Table 1) showed that adopting a faba bean-wheat crop sequence instead of continuous wheat resulted, after 22 years, in significant general improvement in soil quality, as highlighted by improvements observed in almost all biochemical parameters in both the 0 - to 15 -cm layer and the 15to $30-\mathrm{cm}$ layer (Figure 13A and B, respectively). In particular, introducing faba bean into the crop sequence led to a small but significant increase in both the total organic carbon (C) and $\mathrm{N}$ contents (on average $+5 \%$ and $+4 \%$, respectively) and an even larger increase in both the microbial biomass $\mathrm{C}$ and $\mathrm{N}$ contents (on average $+16 \%$ and $+11 \%$, respectively). The respiration indicators $\left(\mathrm{CO}_{2}\right.$ and $\left.\mathrm{qCO}_{2}\right)$ were markedly lower in wheat grown after faba bean compared to the continuous wheat cropping system, especially in the 0 - to $15-\mathrm{cm}$ soil layer. The $\mathrm{CO}_{2}$ and $\mathrm{qCO}_{2}$ parameters are reliable bioindicators of microbial stress and deterioration of soil quality, and their reduction may indicate an increase in soil microbial biomass efficiency, soil quality, and $\mathrm{C}$ sequestration, as observed by other authors (Marschner et al., 2003; Carney et al., 2007; Allison et al., 2010).

Variations in soil biochemical parameters due to the introduction of faba bean into the crop rotation may result in changes in soil microbial community structure, as reported by Alvey et al. (2003) and Bünemann et al. (2004). In our experiment (the same as before, performed within the framework of Exp1, Table 1), the increase in soil microbial biomass due to the introduction of faba bean into the rotation with wheat were linked to an increase in the bacterial community (in both soil layers investigated) of about $+10 \%$ on average, whereas the fungal biomass increased only in the $15-$ to $30-\mathrm{cm}$ soil layer ( $+15 \%$; Figure $14 \mathrm{~A}$ and B). The latter result can be a consequence of the higher $\mathrm{C}$ content observed in the soil, as also reported by other authors (Marschner et al., 2003; Stagnari et al., 2014). Moreover, changes in the extractable $\mathrm{C} / \mathrm{N}$ ratio may have produced a shift in bacteria/fungi between the two soil layers.

Pre-cropping with faba bean increased AM fungi by $10 \%$ and $20 \%$ in the 0 - to $15-\mathrm{cm}$ and $15-$ to $30-\mathrm{cm}$ soil layers, respectively, compared to the continuous wheat cropping system (Figure 14). These results suggest that faba bean as preceding crop is able to increase the potential for AM fungi colonisation for subsequent crops, with all of the benefits that can be derived from this, which include changes in the composition of the bacterial community able to promote plant-beneficial interactions involving hormone production, enhanced nutrient availability, and root health (Marschner and Timonen, 2005; Köpke and Nemecek, 2010).

\section{Conclusions}

Studies carried out over a 25 -year period have provided information on agro-ecological aspects of faba bean cultivation in a typical Mediterranean environment. Considering that most of the research on this species has been conducted in temperate climates, our findings contribute to better defining the role that faba bean can play in improving the sustainability of Mediterranean cropping systems.

On the whole, our studies highlighted the following.

The amount of $\mathrm{N}$ fixed by the aboveground tissues of faba bean was on average $130 \mathrm{~kg} \mathrm{~N} \mathrm{ha}^{-1}$ and in some cases close to 230 $\mathrm{kg} \mathrm{N} \mathrm{ha}{ }^{-1}$. On the whole, faba bean showed a greater ability to fix $\mathrm{N}_{2}$ compared to other grain legumes typically grown in the Mediterranean environment.

Significant relationships were found between $\mathrm{N}$ fixed and shoot dry matter and grain yield, indicating that around 23 and 56 $\mathrm{kg} \mathrm{N}$ are fixed for every megagram of shoot dry matter and grain produced, respectively.

Faba bean was less able than other grain legumes (such as chickpea) to use mineral soil N. Our findings suggest that this may be linked to an asynchrony of $\mathrm{N}$ availability in the soil and plant $\mathrm{N}$ demand.

The low capacity to use mineral soil $\mathrm{N}$ contributes to the increased reliance of the species on $\mathrm{N}_{2}$ fixation to satisfy its $\mathrm{N}$ needs (as highlighted by high values of \%Ndfa even at high levels of soil $\mathrm{N}$ supply) and to high levels of residual mineral $\mathrm{N}$ in the soil at harvest (with $\mathrm{N}$ sparing always higher than other species).

Faba bean was able to establish effective symbiotic relationships with $\mathrm{AM}$ fungi that positively influenced $\mathrm{N}_{2}$ fixation (particularly when plants grew in nutrient-limiting conditions) and also seemed to play a positive role in the transfer of $\mathrm{N}$ to companion crops in intercropping systems.

The increase in soil $\mathrm{N}$ availability (due to both $\mathrm{N}$ spared and $\mathrm{N}$ from crop residues), in addition to other non-N-related benefits, resulted, in comparison with non-legume rotation systems, in considerable increases in yield and quality for the subsequent cereal crop and, to a lesser extent, also the second cereal crop following faba bean. Moreover, pre-cropping with faba bean resulted in an increase in the grain yield stability of the subsequent non-legume crop compared to other preceding crops.

The introduction of faba bean into cropping systems, after an adequate number of years, led to a significant general enhancement in soil quality, highlighted by improvements in most biochemical parameters (total organic $\mathrm{C}$, total organic $\mathrm{N}$, microbial biomass $\mathrm{C}$, etc.) and by significant changes in the structure of the soil microbial community.

No differences were found for $\mathrm{N}_{2} \mathrm{O}$ emissions during the growing season between faba bean and wheat, whereas $\mathrm{NH}_{3}$ emissions were markedly higher in soil under wheat compared to faba bean. Therefore, if one considers the entire cropping system, the introduction of faba bean, which allows a consistent reduction in the use of $\mathrm{N}$ fertilisers for the subsequent crop, leads to a reduction in anthropogenic $\mathrm{N}$ emissions.

On the whole, faba bean shows great value because of the numerous agronomic and environmental benefits it can provide. A relaunching of this crop in Mediterranean cropping systems is certainly desirable, especially if one considers, beyond the aforementioned benefits, the high value of the species as food and feed. To enhance the role of faba bean in the context of more sustainable agriculture, further research is needed to reduce yield instability and maximise its rotational benefits. 


\section{References}

Allison SD, Wallenstein MD, Bradford MA, 2010. Soil-carbon response to warming dependent on microbial physiology. Nat. Geosci. 3:336-40.

Alvey S, Yang CH, Buerkert A, Crowley DE, 2003. Cereal/legume rotation effects on rhizosphere bacterial community structure in west african soils. Biol. Fertil. Soils 37:73-82.

Amato G, Giambalvo D, Frenda AS, Mazza F, Ruisi P, Saia S, Di Miceli G, 2016. Sulla (Hedysarum coronarium L.) as potential feedstock for biofuel and protein. BioEnergy Res. 9:711-9.

Amato G, Ruisi P, Frenda AS, Di Miceli G, Saia S, Plaia A, Giambalvo D, 2013. Long-term tillage and crop sequence effects on wheat grain yield and quality. Agron. J. 105:131727.

Anglade J, Billen G, Garnier J, 2015. Relationships for estimating $\mathrm{N}_{2}$ fixation in legumes: incidence for $\mathrm{N}$ balance of legumebased cropping systems in Europe. Ecosphere 6:37.

Barton L, Butterbach-Bahl K, Kiese R, Murphy DV, 2011. Nitrous oxide fluxes from a grain-legume crop (narrow-leafed lupin) grown in a semiarid climate. Global Change Biol. 17:1153-66.

Bünemann EK, Bossio DA, Smithson PC, Frossard E, Oberson A, 2004. Microbial community composition and substrate use in a highly weathered soil as affected by crop rotation and $\mathrm{P}$ fertilization. Soil Biol. Biochem. 36:889-901.

Carney KM, Hungate BA, Drake BG, Megonigal JP, 2007. Altered soil microbial community at elevated $\mathrm{CO}_{2}$ leads to loss of soil carbon. P. Natl. Acad. Sci. USA 104:4990-5.

Chalk PM, Peoples MB, McNeill AM, Boddey RM, Unkovich MJ, Gardener MJ, Silva CF, Chen D, 2014. Methodologies for estimating nitrogen transfer between legumes and companion species in agro-ecosystems: a review of ${ }^{15} \mathrm{~N}$-enriched techniques. Soil Biol. Biochem. 73:10-21.

Chalk PM, Smith CJ, Hamilton SD, Hopmans P, 1993. Characterization on the $\mathrm{N}$ benefit of a grain legume (Lupinus angustifolius L.) to a cereal (Hordeum vulgare L.) by an in situ ${ }^{15} \mathrm{~N}$ isotope dilution technique. Biol. Fertil. Soils 15:39-44.

Champ M, 2002. Foreword. Brit. J. Nutr. 88:237.

Crews TE, Peoples MB, 2005. Can the synchrony of nitrogen supply and crop demand be improved in legume and fertilizerbased agroecosystems? A review. Nutr. Cycl. Agroecosyst. 72:101-20.

Dick J, Kaya B, SoutouraM, Skiba U, Smith R, Niang A, Tabo R, 2008. The contribution of agricultural practices to nitrous oxide emissions in semi-arid Mali. Soil Use Manage. 24:292301.

FAOSTAT, 2016. Food and Agriculture Organization of the United Nations, Statistics Division. Available from: http://faostat3. fao.org/home/

Frühbeck G, Monreal I, Santidrian S, 1997. Hormonal implications of the hypocholesterolemic effect of intake of field beans (Vicia faba L.) by young men with hypercholesterolemia. Am. J. Clin. Nutr. 66:1452-60.

Giambalvo D, Ruisi P, Saia S, Di Miceli G, Frenda AS, Amato G, 2012. Faba bean grain yield, $N_{2}$ fixation, and weed infestation in a long-term tillage experiment under rainfed Mediterranean conditions. Plant Soil 360:215-27.

Giambalvo D, Stringi L, Di Miceli G, Scarpello C, 2003. Biological nitrogen fixation in faba bean and chickpea under Mediterranean conditions. Riv. Agron. 37:129-32.

Giambalvo D, Stringi L, Durante G, Amato G, Frenda AS, 2004. Nitrogen efficiency component analysis in wheat under rainfed
Mediterranean conditions: effects of crop rotation and nitrogen fertilization. Options Méditerr. Serie A 60:169-73.

Giambalvo D, Stringi L, Trapani P, Di Miceli G, Frenda AS, Amato G, 2007. Azotofissazione nel cece in ambiente mediterraneao. In Proc. XXXVII SIA Congr., 13-14 September 2007, Catania, Italy. pp 267-8.

Gregory PJ, 1988. Root growth of chickpea, faba bean, lentil, and pea and effects of water and salt stresses. In: R.J. Summerfield (ed.). World crops: cool season food legumes. Kluwer Academic Publ., Dordrecht, the Netherlands. pp 857-67.

Hauggaard-Nielsen H, Mundus S, Jensen ES, 2009. Nitrogen dynamics following grain legumes and subsequent catch crops and the effects on succeeding cereal crops. Nutr. Cycling Agroecosyst. 84:281-91.

Hernanz JL, López R, Navarrete L, Sánchez-Girón V, 2002. Longterm effects of tillage systems and rotations on soil structural stability and organic carbon stratification in semiarid central Spain. Soil Till. Res. 66:129-41.

Høgh-Jensen H, 2006. The nitrogen transfer between plants: an important but difficult flux to quantify. Plant Soil 282:1-5.

Jensen ES, Peoples MB, Boddey RM, Gresshoff PM, HauggaardNielsen H, Alves BJ, Morrison MJ, 2012. Legumes for mitigation of climate change and the provision of feedstock for biofuels and biorefineries. A review. Agron. Sustain. Dev. 32:32964.

Jensen ES, Peoples MB, Hauggaard-Nielsen H, 2010. Faba bean in cropping systems. Field Crop. Res. 115:203-16.

Kirkegaard J, Christen O, Krupinsky J, Layzell D, 2008. Break crop benefits in temperate wheat production. Field Crop. Res. 107:185-95.

Köpke U, Nemecek T, 2010. Ecological services of faba bean. Field Crop. Res. 115:217-33.

Lamb JF, Jung HJG, Riday H, 2014. Growth environment, harvest management and germplasm impacts on potential ethanol and crude protein yield in alfalfa. Biomass Bioenerg. 63:114-25.

López-Bellido L, Fuentes M, Castillo JE, López-Garrido FJ, Fernández EJ, 1996. Long-term tillage, crop rotation, and nitrogen fertilizer effects on wheat yield under rainfed Mediterranean conditions. Agron. J. 88:783-91.

Marschner P, Kandeler E, Marschner B, 2003. Structure and function of the soil microbial community in a long-term fertilizer experiment. Soil Biol. Biochem. 35:453-61.

Marschner P, Timonen S, 2005. Interactions between plant species and mycorrhizal colonization on the bacterial community composition in the rhizosphere. Appl. Soil Ecol. 28:23-36.

McDaniel MD, Tiemann LK, Grandy AS, 2014. Does agricultural crop diversity enhance soil microbial biomass and organic matter dynamics? a meta-analysis. Ecol. Appl. 24:560-70.

Mosier A, Kroeze C, 2000. Potential impact on the global atmospheric $\mathrm{N}_{2} \mathrm{O}$ budget of the increased nitrogen input required to meet future global food demands. Chemosphere-Global Change Sci. 2:465-73.

Ofuya ZM, Akhidue V, 2005. The role of pulses in human nutrition: a review. J. Appl. Sci. Environ. Manage. 9:99-104.

Peoples MB, Brockwell J, Herridge DF, Rochester IJ, Alves BJR, Urquiaga S, Boddey RM, Dakora FD, Bhattarai S, Maskey SL, Sampet C, Rerkasem B, Khan DF, Hauggaard-Nielsen H, Jensen ES, 2009. The contributions of nitrogen-fixing crop legumes to the productivity of agricultural systems. Symbiosis 48:1-17.

Peoples MB, Ladha JK, Herridge DF, 1995. Enhancing legume $\mathrm{N}_{2}$ fixation through plant and soil management. Plant Soil 174:83101. 
Petersson A, Thomsen MH, Hauggaard-Nielsen H, Thomsen AB, 2007. Potential bioethanol and biogas production using lignocellulosic biomass from winter rye, oilseed rape and faba bean. Biomass Bioenerg. 31:812-9.

Preissel S, Reckling M, Schläfke N, Zander P, 2015. Magnitude and farm-economic value of grain legume pre-crop benefits in Europe: a review. Field Crop. Res. 175:64-79.

Ramu K, Watanabe T, Uchino H, Sahrawat KL, Wani SP, Ito O, 2012. Fertilizer induced nitrous oxide emissions from Vertisols and Alfisols during sweetsorghum cultivation in the Indian semi-arid tropics. Sci. Total Environ. 438:9-14.

Rennie RJ, Dubetz S, 1986. Nitrogen-15-determined nitrogen fixation in field-grown chickpea, lentil, fababean and field pea. Agron. J. 78:654-60.

Rochester IJ, Peoples MB, Constable GA, Gault RR, 1998. Faba beans and other legumes add nitrogen to irrigated cotton cropping systems. Aust. J. Exp. Agric. 38:253-60.

Rochester IJ, Peoples MB, Hulugalle NR, Gault RR, Constable GA, 2001. Using legumes to enhance nitrogen fertility and improve soil condition in cotton cropping systems. Field Crop. Res. 70:27-41.

Rochette P, Janzen HH, 2005. Towards a revised coefficient for estimating $\mathrm{N}_{2} \mathrm{O}$ emissions from legumes. Nutrient Cycl. AgroEcosyst. 73:171-9.

Ruisi P, Frangipane B, Amato G, Badagliacca G, Di Miceli G, Plaia A, Giambalvo D, 2015. Weed seedbank size and composition in a long-term tillage and crop sequence experiment. Weed Res. 55:320-8.

Ruisi P, Giambalvo D, Di Miceli G, Frenda AS, Saia S, Amato G, 2012. Tillage effects on yield and nitrogen fixation of legumes in Mediterranean conditions. Agron. J. 104:1459-66.

Ruisi P, Saia S, Badagliacca G, Amato G, Frenda AS, Giambalvo D, Di Miceli G, 2016. Long-term effects of no tillage treatment on soil $\mathrm{N}$ availability, $\mathrm{N}$ uptake, and ${ }^{15} \mathrm{~N}$-fertilizer recovery of durum wheat differ in relation to crop sequence. Field Crop. Res. 189:51-8.

Saia S, Benitez E, Garcia-Garrido JM, Settanni L, Amato G, Giambalvo D, 2014. The effect of arbuscular mycorrhizal fungi on total plant nitrogen uptake and nitrogen recovery from soil organic material. J. Agric. Sci. 152:370-8.

Saia S, Urso V, Amato G, Frenda AS, Giambalvo D, Ruisi P, Di Miceli G, 2016. Mediterranean forage legumes grown alone or in mixture with annual ryegrass: biomass production, $\mathrm{N}_{2}$ fixation, and indices of intercrop efficiency. Plant Soil 402:395407.

Salvagiotti F, Cassman KG, Specht JE, Walters DT, Weiss A,
Dobermann A, 2008. Nitrogen uptake, fixation and response to fertilizer N in soybeans: a review. Field Crop. Res. 108:1-13.

Schwenke GD, Peoples MB, Turner GL, Herridge DF, 1998. Does nitrogen fixation of commercial, dryland chickpea and faba bean crops in north-west New South Wales maintain or enhance soil nitrogen? Aust. J. Exp. Ag. 38:61-70.

Senbayram M, Wenthe C, Lingner A, Isselstein J, Steinmann H, Kaya C, Köbke S, 2016. Legume-based mixed intercropping systems may lower agricultural born $\mathrm{N}_{2} \mathrm{O}$ emissions. Energy Sustain. Soc. 6:1.

Smith SC, Bezdicek RF, Turco RF, Cheng HH, 1987. Seasonal $\mathrm{N}_{2}$ fixation by cool-season pulses based on several ${ }^{15} \mathrm{~N}$ methods. Plant Soil 97:3-13.

Stagnari F, Perpetuini G, Tofalo R, Campanelli G, Leteo F, Della Vella U, Schirone M, Suzzi G, Pisante M, 2014. Long-term impact of farm management and crops on soil microorganisms assessed by combined DGGE and PLFA analyses. Front. Microbiol. 5:644.

Sulas L, Roggero PP, Canu S, Seddaiu G, 2013. Potential nitrogen source from field bean for rainfed Mediterranean cropping systems. Agron. J. 105:1735-42.

Tanno KI, Willcox G, 2006. The origins of cultivation of Cicer arietinum L. and Vicia faba L.: early finds from Tell el-Kerkh, north-west Syria, late $10^{\text {th }}$ millennium BP. Veg. Hist. Archaeobot. 15:197-204.

Turpin JE, Herridge DF, Robertson MJ, 2002. Nitrogen fixation and soil nitrate interactions in field-grown chickpea (Cicer arietinum) and faba bean (Vicia faba). Aust. J. Agric. Res. 53:599-608.

Unkovich MJ, Baldock J, Peoples MB, 2010. Prospects and problems of simple linear models for estimating symbiotic $\mathrm{N}_{2}$ fixation by crop and pasture legumes. Plant Soil 329:75-89.

USDA Soil Taxonomy, 2010. Keys to soil taxonomy, 11th ed. USDA Natural Resources Conservation Service, Washington, DC, USA.

van Kessel C, Hartley C, 2000. Agricultural management of grain legumes: has it led to an increase in nitrogen fixation? Field Crop. Res. 65:165-81.

Walley FL, Clayton GW, Miller PR, Carr PM, Lafond GP, 2007. Nitrogen economy of pulse crop production in the northern great plains. Agron. J. 99:1710-8.

Wright AT, 1990. Yield effect of pulses on subsequent cereal crops in the northern prairies. Can. J. Plant Sci. 70:1023-32. 